\title{
How to Protect Natural Habitats of Rare Terrestrial Orchids Effectively: A Comparative Case Study of Cypripedium calceolus in Different Geographical Regions of Europe
}

\author{
Anna Jakubska-Busse ${ }^{1, * \mathbb{D}}$, Spyros Tsiftsis ${ }^{2} \mathbb{D}$, Michał Śliwiński ${ }^{3}$, Zdenka Křenová ${ }^{4,5} \mathbb{D}^{\mathbb{D}}$, Vladan Djordjević $^{6} \mathbb{D}$, \\ Corina Steiu ${ }^{7}$, Marta Kolanowska ${ }^{4,8}$, Petr Efimov ${ }^{9}$, Sebastian Hennigs ${ }^{10}$, Pavel Lustyk ${ }^{11_{(D)}}$ \\ and Karel (C.A.J.) Kreutz ${ }^{12}$
}

check for updates

Citation: Jakubska-Busse, A.; Tsiftsis, S.; Śliwiński, M.; Křenová, Z.; Djordjević, V.; Steiu, C.;

Kolanowska, M.; Efimov, P.;

Hennigs, S.; Lustyk, P.; et al. How to Protect Natural Habitats of Rare Terrestrial Orchids Effectively: A Comparative Case Study of Cypripedium calceolus in Different Geographical Regions of Europe. Plants 2021, 10, 404. https:// doi.org/10.3390/plants10020404

Academic Editor: Dennis Whigham

Received: 24 January 2021

Accepted: 12 February 2021

Published: 20 February 2021

Publisher's Note: MDPI stays neutral with regard to jurisdictional claims in published maps and institutional affiliations.

Copyright: (c) 2021 by the authors. Licensee MDPI, Basel, Switzerland. This article is an open access article distributed under the terms and conditions of the Creative Commons Attribution (CC BY) license (https:/ / creativecommons.org/licenses/by/ $4.0 /)$.
1 Department of Botany, Institute of Environmental Biology, University of Wrocław, Kanonia Street 6/8, 50-328 Wrocław, Poland

2 Department of Forest and Natural Environment Sciences, International Hellenic University, GR-66132 Drama, Greece; stsiftsis@for.ihu.gr

3 Lower Silesian Ecological Club, Piłsudskiego Street 74, PL-50-020 Wrocław, Poland; michal.sliwinski@o2.pl

4 Department of Biodiversity Research, Global Change Research Institute AS CR, Bělidla 4a, 60300 Brno, Czech Republic; zd.krenova@gmail.com (Z.K); marta.kolanowska@biol.uni.lodz.pl (M.K.)

5 Institute for Environmental Studies, Faculty of Science, Charles University, Benátská 2, CZ-12900 Prague, Czech Republic

6 Institute of Botany and Botanical Garden, Faculty of Biology, University of Belgrade, Takovska 43, 11000 Belgrade, Serbia; vdjordjevic@bio.bg.ac.rs

7 Association P.P.V.N.C. Excelsior, Timisoara branch, 310465 Timisoara, Romania; corinaepipactis@gmail.com

8 Department of Geobotany and Plant Ecology, Faculty of Biology and Environmental Protection, University of Łódź, Banacha 12/16, 90-237 Łódź, Poland

9 Komarov Botanical Institute of the Russia Academy of Sciences, 197376 Saint-Petersburg, Russia; efimov81@mail.ru

10 Berliner Allee 191, D-13088 Berlin, Germany; info@hennigs-photography.de

11 Nature Conservation Agency of the Czech Republic, Kaplanova 1931/1, CZ-14800 Prague, Czech Republic; pavel-lustyk@seznam.cz

12 Department of Botany, Naturalis Biodiversity Center, 2300 RA Leiden, The Netherlands; karel.kreutz@naturalis.nl

* Correspondence: anna.jakubska-busse@uwr.edu.pl; Tel.: +48 (71)-375-4081; Fax: +48 (71) 325-4118
Abstract: In this article we present and discuss the main factors that threaten natural populations of Cypripedium calceolus (lady's slipper orchid) in Europe, and we propose conservation strategies and directions for protective actions of its population on a regional scale. European C. calceolus populations have decreased significantly in the last two decades, in both number and size. A key result of the present study is an evaluation of the effectiveness of the Natura 2000 network across the European Union (EU) countries. Northern and/or mountainous countries present higher percentages of potentially suitable areas within the Natura 2000 network. Finland and the United Kingdom are the exceptions to this rule. It is predicted that, due to global warming, the coverage of niches suitable for C. calceolus will decrease in countries in which now-healthy colonies exist. However, as plant species can occur in micro-sites with suitable environmental conditions (e.g., microclimate, vegetation, soil factors) which cannot be predicted as suitable at coarser spatial resolutions, conservation efforts should be focused on management of local healthy populations. For the effective protection of C. calceolus in Natura 2000 sites, the participation of experts in botany, including orchid biology, is necessary at several stages.

Keywords: Cypripedium calceolus; orchids; conservation biology; threatening processes; climate changes; appropriate management 


\section{Introduction}

Since the end of the 18th century, it has been realized that anthropogenic effects on the natural environment are often destructive, and that action should be taken to conserve animal and plant species. Nowadays, the European Union (EU) Natura 2000, a network of protected areas designated under the Birds and Habitats Directives (2009/147/EC and 92/43/EEC, respectively), has been established across all $27 \mathrm{EU}$ countries (the UK is considered a member state for the purposes of this paper). With more than 25,000 sites, covering over $18 \%$ of the EU's land area and more than $8 \%$ of its marine territory, Natura 2000 is the largest coordinated network of protected areas in the world. More than 1000 animal and plant species, as well as 200 habitat types, as listed in the Directives' Annexes, should be protected and appropriately managed to conserve EU biodiversity [1].

Of the orchids that have been recorded in EU countries, four species are listed in Annex II of the Habitats Directive: Cephalanthera cucullata Boiss and Heldr., Cypripedium calceolus L., Liparis loeselii (L.) Rich., and Ophrys lunulata Parl. Of these, C. cucullata and O. lunulata are endemics of Crete and of Sicily (and some nearby islands), respectively [2]. By contrast, L. loeselii is widely distributed in the northern hemisphere but is found only in fens, bogs, and dune slacks; its habitat specialization makes it extremely rare and threatened [3]. Cypripedium calceolus is a Eurasian taxon which also occurs from the Crimea through Siberia to Mongolia, China, and Japan [4,5]. It is found in large parts of northern Asia as far east as the Primorye Region of Russia [6], and it has recently been found in a totally isolated area in Algeria [7]. In Europe, the center of this species' occurrence is in central and northern parts of the continent, while it is totally absent in the evergreen Mediterranean zone [8].

Across its global range, C. calceolus is regarded as a species of least concern according to the International Union for Conservation of Nature (IUCN) [9]. Notwithstanding its global status, in some countries it has been characterized as a species fulfilling the criteria for inclusion in threatened categories (for details see [10]). Moreover, C. calceolus is included under Appendix I of the Convention on International Trade in Endangered Species of Wild Fauna and Flora (CITES), under Appendix I of the Convention on the Conservation of European Wildlife and Natural Habitats (Bern Convention), is fully protected under Schedule 8 of the Wildlife and Countryside Act 1984, and is listed on Schedule 4 of the Conservation Regulations [3,11]. Information about its status in European countries can be found in Kull et al. [10], but in other territories it is often very rare and threatened with extinction, as in the Crimea, where it grows only in a single locality [12].

As a species with a high conservation value, C. calceolus is the only European orchid species for which an Action Conservation Plan has been published [8]. Despite its high protection status, C. calceolus is one of the European wild orchid species that has significantly declined during last two decades [8,9]. This is largely due to external factors causing disturbances of habitat conditions [13]. Progressive habitat loss, ending of traditional forest management (e.g., coppicing, small clearings), illegal digging-up for gardens, and improperly carried-out in situ conservation measures have reduced both the number of populations and the population sizes in Poland [14,15], as well as in other European countries [8].

Although, the aforementioned threats are expected to affect C. calceolus directly, through the reduction of its populations or of the number of individuals in those populations, the effects of the climate change are also expected to affect native plant species. Specifically, the recently recorded increase in summer temperatures, drought, large-scale fires, and lack of snow in winter tend to cause declines in the distribution ranges of several plant species, or to force them to migrate towards northern latitudes and higher altitudes $[16,17]$. Kolanowska and Jakubska-Busse [15], in their study of the effects of climate change on C. calceolus found that its range will decrease by ca. 30-63\% by 2070 . This is a big challenge for biodiversity conservation, especially when protected areas are in the lowlands and their environmental heterogeneity is low [18]. Regarding the effectiveness of the Natura 2000 network under future climatic conditions, Araújo et al. [19] found that areas of suitable climate will decrease for a significant number of the species of 
European concern occurring in Natura 2000 areas. In the light of future climate change, the effectiveness of the Natura 2000 network in conserving species of European concern could also be enhanced by a set of management measures that would ensure the existence of a variety of micro-habitats, suitable for most of these species.

Plant species are expected to respond to such changing environments in different ways. Thus, detailed knowledge of a species' ecology [20], its current threat and conservation status, and the appropriate management requirements are essential for effective conservation in the future which will have to happen through a quick response from scientists, conservationists, forest managers and all other stakeholders.

The aims of the present study are: (1) to summarize the conservation status, major threats, and threatening processes to the natural populations of $C$. calceolus in different geographical regions; (2) to explore the effectiveness of the Natura 2000 network of protected areas under current and future climatic conditions; (3) to identify the characteristics of the habitats and plant communities in which C. calceolus grows in the center of its distribution; and (4) to provide examples of good management practice across its European distribution range.

We believe that our conclusions can improve C. calceolus conservation in Europe significantly, and that successful conservation of such an iconic species can inspire and support conservation for European biodiversity overall.

\section{Materials and Methods}

\subsection{Study Species}

Cypripedium calceolus L. 1753, the lady's slipper orchid, is a long-lived, rhizomatous, terrestrial, cross-fertilized plant species e.g., [21-23], which grows in lightly shaded deciduous and mixed woodland (rarely in full sunlight, often in coppicing forests) and in meadows, predominantly on calcareous soils [23], as well as in deciduous and coniferous forests with an understory of grasses and other herbs, in forest clearings and lean pastures, often near stream banks, and in bushy hillsides. At the southern limits of its distribution it is found mostly in beech forests at montane and submontane elevations [8,24] and Appendix A.

Its altitudinal preferences vary from country to country, correlated with the latitudinal gradient. Specifically, its altitudinal range starts from the mid-elevation zone (e.g., Serbia, 1350-1650 m a.s.1.; Croatia, 500-1700 m a.s.1.); it occurs at higher altitudes in southern countries (e.g., Bulgaria: $1340 \mathrm{~m}$ a.s.1.), while towards the northern European countries it can be found from the lowlands up to $2200 \mathrm{~m}$ a.s.l. [25]; e.g., Finland, 10-262 m a.s.l.; Denmark, $75 \mathrm{~m}$ a.s.l.; Britain, 150-260 m a.s.1.; Poland, 77-1046 m a.s.1.; Germany, 10-1540 m a.s.1.). This differentiation indicates that conservation practices and measures should be organized according to location.

\subsection{Conservation Status and Threats that Cypripedium calceolus Faces in Europe}

To identify the major threats for C. calceolus in Europe, and to propose appropriate management measures, we used information obtained from a variety of sources published in the years 1993-2020 - e.g., books, webpages, research articles-with expert knowledge used in cases where the necessary information was not otherwise directly available. The information that was used included (a) the most up-to-date IUCN threat category of C. calceolus for all European countries e.g., [26], Appendix B, (b) the criteria of the IUCN that C. calceolus meets in each country: A - population reduction, $\mathrm{B}$ - geographic range, $\mathrm{C}$ - small population size and decline, D-very small or restricted population, E-quantitative analysis [27], and (c) the factors that threaten the existence and survival of C. calceolus, as: collecting, clear cutting of the woods, grazing, damage by rodents, changes in the dominant tree species, habitat destruction, trampling, road construction, global heating, habitats drainage, forest and grassland fires, eutrophication, animal pests, grassland mowing or other stochastic events. However, data concerning the criteria of the IUCN and/or specific threats for C. calceolus were not available for all countries and some of the criteria could not be applied 
without presence of historical data. In the case of Ukraine, where IUCN criteria were not available, we tried to determine these on the basis of available chorological and population data $[28,29]$. To identify clusters of countries with a high degree of similarity in the threats that $C$. calceolus faces, we applied an unweighted pair group method with arithmetic mean (UPGMA) cluster algorithm using the Bray-Curtis similarity index. The UPGMA method was performed in $\mathrm{R}$ v. 4.0.2, using the vegan package [30].

\subsection{Effectiveness of the Natura 2000 Network in Conserving Cypripedium calceolus}

The degree of effectiveness of the Natura 2000 network was explored using the published results of Kolanowska and Jakubska-Busse [15] regarding the current and future potential distribution of Cypripedium calceolus. Specifically, in their study Kolanowska and Jakubska-Busse [15] used maximum entropy techniques [31-33] to predict the potential distribution of this orchid. They used 12 bioclimatic variables (bio1: annual mean temperature; bio2: mean diurnal range; bio3: isothermality; bio4: temperature seasonality; bio5: max temperature of warmest month; bio8: mean temperature of wettest quarter; bio12: annual precipitation; bio13: precipitation of wettest month; bio14: precipitation of driest month; bio15: precipitation seasonality; bio18: precipitation of warmest quarter; bio19: precipitation of coldest quarter) at a spatial resolution of $2.5 \mathrm{~min}$ (approximately $22 \mathrm{~km}$ ), and their predictions were based on the Community Climate System Model (CCSM4) for the year 2070, using four available representative concentration pathways (RCPs: rcp2.6, rcp4.5, rcp6.0 and rcp8.5). To explore the importance of the Natura 2000 network of protected areas, we used the sites of community importance (SCIs), as well as the special areas for conservation (SACs) downloaded from the European Environment Agency. The list of Natura 2000 habitats in exemplary European countries was prepared on the basis of published data e.g., [12,34-39]; for details see Appendix A.

Due to their coarse spatial scale, direct use of the predicted potential distributions of Cypripedium calceolus [15] would not allow an accurate estimation of the effectiveness of the Natura 2000 network in conserving C. calceolus under current and future climatic conditions. To overcome this problem, we increased the spatial resolution by resampling the initial raster layers of the predictions to $30 \mathrm{~s}$ resolution (approximately $1 \mathrm{~km}^{2}$ ). As the output of the species-distribution models is a continuous habitat-suitability map, we had to convert the habitat-suitability maps into binary maps using a cut-off value as a threshold in order to identify areas that are potentially suitable for C. calceolus. In accordance with the results presented by Kolanowska and Jakubska-Busse [15], the habitat-suitability cut-off value was set as 0.4 , with values at or above that threshold set as presences and values below as absences.

Additionally, the vector file corresponding to sites of community importance and to special areas for conservation was converted into a raster layer with the same spatial resolution and extent as the resampled raster layers of the binary predictions. We then converted this modified raster layer into a point shapefile, wherein points correspond to the centroids of the resampled raster grids (raster layers of the predictions). As final steps, we extracted values of the predictions of $C$. calceolus under current and future climatic conditions for each point of the point shapefile and measured the number of grid cells of the Natura 2000 network for each of the EU countries corresponding to the presence of C. calceolus.

\section{Results}

The IUCN threat status of Cypripedium calceolus, as well as the criteria that it fulfills, are presented in Table 1 for each European country. In total, the species is present, or has been recorded, in 35 countries or areas, including the European part of Russia and in Crimea, whereas it has never been recorded in seven countries, where it is, therefore, considered absent (Iceland, Ireland, Cyprus, Portugal, North Macedonia, and Malta). It is extinct in five countries (Table 1), and classified as threatened (Critically Endangered (CR), Endangered (EN), or Vulnerable (VU)) in 22 out of the 35 countries of Europe (i.e., $62 \%$ ). 
The most common threat category was that of 'Vulnerable' (11/35 countries; $31 \%)$, followed by 'Critically Endangered' $(6 / 35 ; 17 \%)$ and 'Endangered' (5/25; 14\%). Moreover, in another five countries, C. calceolus was classified in the 'Near Threatened' category, whereas it is considered as of 'Least Concern' in only three European countries (9\%; Table 1).

Table 1. Threat status in European countries, by International Union for Conservation of Nature (IUCN) categories.

\begin{tabular}{|c|c|c|c|c|c|c|}
\hline \multirow{2}{*}{ Country/Area } & \multirow{2}{*}{$\begin{array}{l}\text { IUCN } \\
\text { Category }\end{array}$} & \multicolumn{5}{|c|}{ IUCN Criteria } \\
\hline & & A & B & $\mathrm{C}$ & D & $\mathbf{E}$ \\
\hline $\begin{array}{l}\text { Belgium, Greece, Liechtenstein, Luxemburg, The } \\
\text { Netherlands }\end{array}$ & EX & - & - & - & - & - \\
\hline Bulgaria, Crimea & $\mathrm{CR}$ & - & 1 & 1 & 1 & - \\
\hline Serbia & $\mathrm{CR}$ & - & 1 & 1 & - & - \\
\hline Moldova & $\mathrm{CR}$ & - & 1 & - & 1 & - \\
\hline Bosnia and Herzegovina & $\mathrm{CR}$ & 1 & - & - & - & - \\
\hline United Kingdom & $\mathrm{CR}$ & - & - & - & 1 & - \\
\hline Croatia, Hungary & EN & 1 & - & - & - & - \\
\hline Montenegro & EN & - & - & - & 1 & - \\
\hline Ukraine & EN & - & 1 & - & - & - \\
\hline Spain & EN & - & - & 1 & - & - \\
\hline Germany & VU & 1 & 1 & - & - & - \\
\hline Belarus, France, Latvia, Lithuania, Slovenia & VU & 1 & - & - & - & - \\
\hline Poland, Romania, Switzerland & VU & - & 1 & - & - & - \\
\hline Czech Republic & VU & - & - & 1 & - & - \\
\hline Denmark & VU & - & - & - & 1 & - \\
\hline $\begin{array}{l}\text { Austria, Estonia, Finland, Slovak Republic, } \\
\text { Norway }\end{array}$ & NT & - & - & - & - & - \\
\hline Italy, Russia (European part), Sweden & LC & - & - & - & - & - \\
\hline \multicolumn{7}{|c|}{ EX: Extinct; CR: Critically Endangered; EN: Endangered; VU: Vulnerable; NT: Near Threatened; LC: Least Concern } \\
\hline Countries where C. calceolus is absent: & nia, Cyprus & nd, I & -1 & Mac & & \\
\hline
\end{tabular}

The classification of a species in any of the three threat categories of the IUCN (CR, $E N$, and VU) is based on a series of five different criteria $(A, B, C, D$, and $E)$. As can be seen in Table 1, the most common criteria are A and B (C. calceolus meets these criteria in $41 \%$ of the countries where it was classified as threatened), followed by criteria D and C (27\%, 23\% of those countries). Criterion $\mathrm{E}$ was not met in any of the countries where the species has been classified in a threat category.

With the exception of the United Kingdom, where C. calceolus is characterized as critically endangered, its IUCN threat status is higher towards the southern European countries (Figure 1). In most countries of the Balkan Peninsula, C. calceolus is classified in the highest IUCN threat categories (i.e., critically endangered or vulnerable); it is absent from the southernmost countries, and extinct in Greece. By contrast, as a species of northern origin C. caleolus is of least concern or near threatened towards the northern-European countries, and especially in Scandinavia. A second, but smaller, core of countries where the species has been characterized as near threatened or of least concern is in central Europe, specifically Italy, Austria, and Slovakia (Figure 1). 


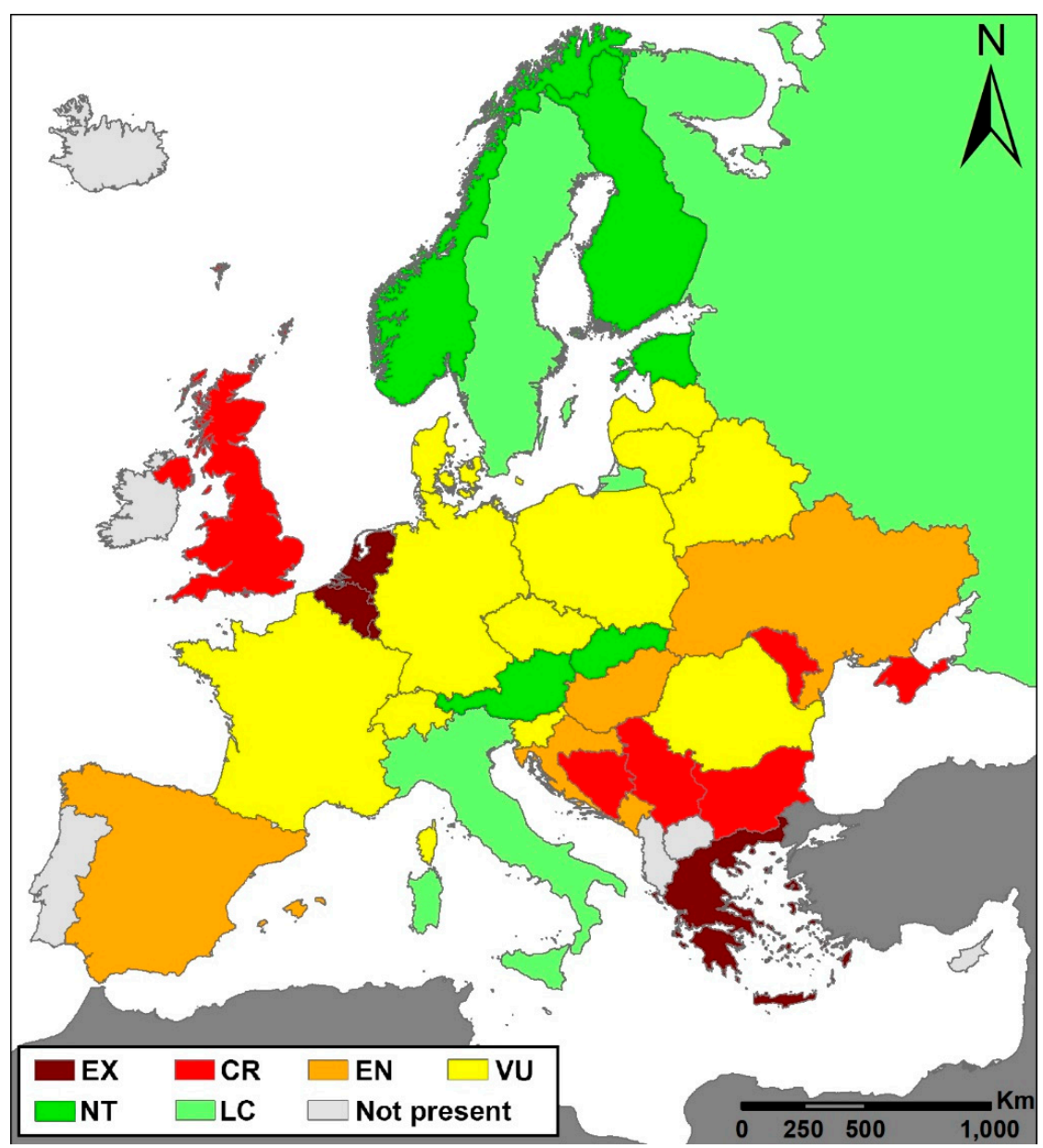

Figure 1. Map of Europe presenting the IUCN threat category of Cypripedium calceolus in each country. The map was created using the projected coordinate system "Lambert_Azimuthal_Equal_Area".

Where possible (data from 30 countries were available), the factors offering the greatest threats to C. calceolus were identified (Table 2). Collecting (reported as a threat in 25 countries), vegetation succession (20 countries), and clear cutting of the woods (19 countries) are the most common threats, followed by grazing and damage by rodents ( 7 countries), changes in the dominant tree species (6 countries), and habitat destruction (6 countries). On the other hand, eutrophication, animal pests (insects, snails), inappropriate grassland mowing, fragmentation, and other stochastic events are the least common factors regarding the number of countries in which these have been identified as threats.

Five groups of countries can be distinguished in which the factors that threaten C. calceolus are identical or similar (Figure 2). Austria stands alone in having eutrophication and changes in the dominant tree species identified as the major threats for C. calceolus; these factors were minor elsewhere, and reported from only a few other countries.

Regarding the spatial distribution of the threats, towards the south of the orchid's distribution range (in the Balkans) threats are mostly related to collection, and secondarily to the clear cutting of the woods where C. calceolus occurs (Table 2, Figure 3). Bulgaria and Ukraine were grouped together because, aside from collecting, forest fires constitute a serious threat for C. calceolus. In the central and northern parts of the range, collecting, clear cutting of woods, and vegetation succession have been identified as major threats. However, within this single large group, two smaller groups can be recognized (2nd and 3rd groups). While collecting, clear cutting, and vegetation succession are the most serious factors in more than half of these countries, in the remainder (Hungary, Spain, Finland, Belarus, Czech Republic, and Switzerland) other aspects, such as trampling and grazing 
damage by rodents, are also important. It is essential to understand the grazing herd size in order to establish a grazing plan with no overgrazing [40].

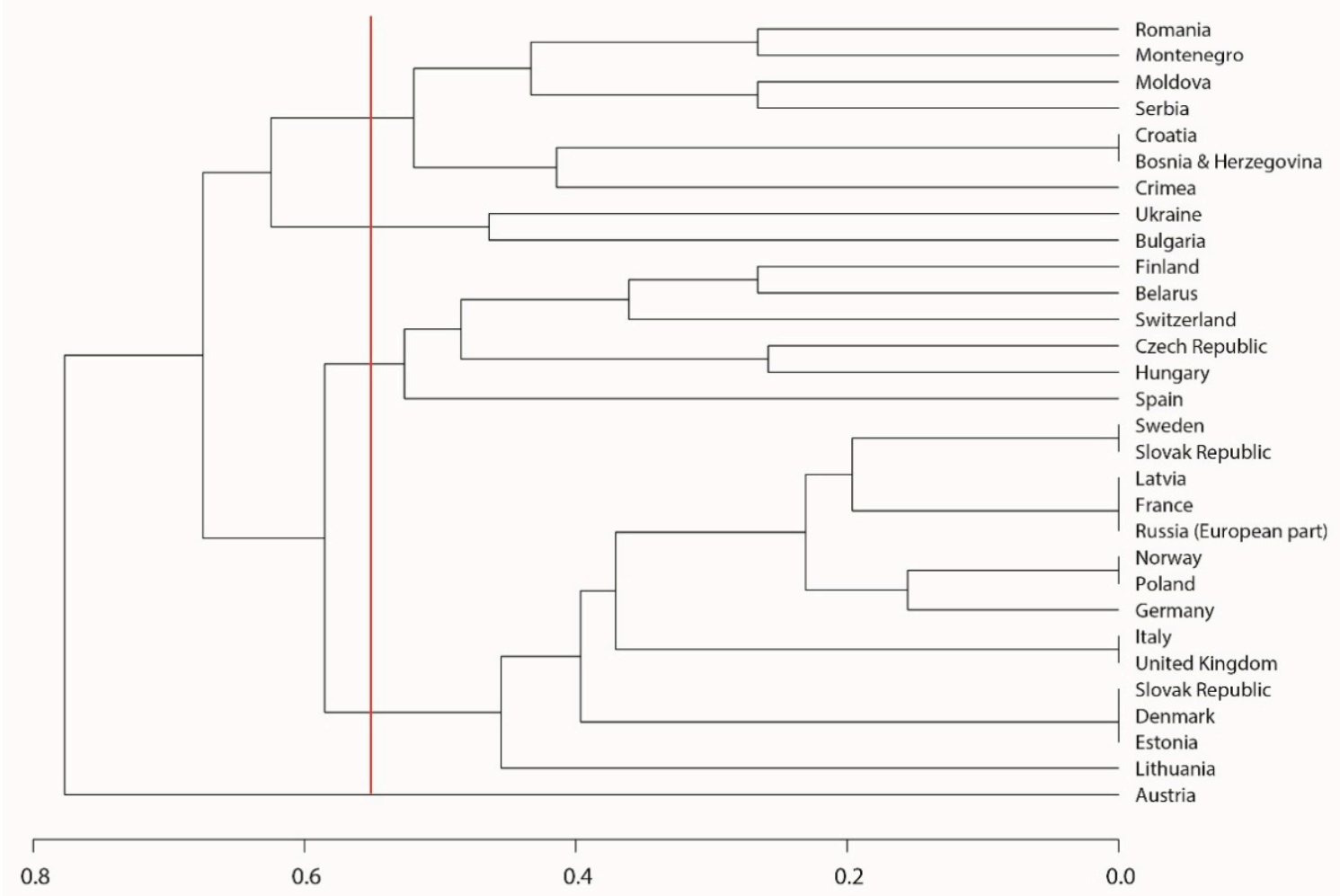

Figure 2. Results of hierarchical cluster analysis (unweighted pair group method with arithmetic mean, UPGMA) showing the degree of similarity of European countries where Cypripedium calceolus is present, using Bray-Curtis distances of the factors that have been identified as threats at each country. The vertical red line denotes the limit that led to the identification of the five groups of countries.

Despite an awareness that the occurrence of Cypripedium calceolus is limited by many environmental attributes (e.g., habitat, geology, and biotic interactions), as well as by historical factors, we elected to calculate the potentially suitable area for $C$. calceolus within the Natura 2000 network of EU members, constrained only by current and future climatic conditions (Table 3). The results necessarily overestimate the actual candidate areas, because ecological conditions in many Natura 2000 sites do not meet $C$. calceolus environmental requirements; nevertheless, this calculation helps better inform an understanding of the importance of changing climatic conditions. Under current conditions, the Czech Republic, Austria, Luxembourg, and the Slovak Republic have the greatest percentages of potentially suitable areas within their Natura 2000 networks, while Greece, Spain, Finland, the United Kingdom, and Belgium are characterized by the lowest percentages. However, under future climatic conditions, as based on the Community Climate System Model for the year 2070 (CCSM4; RCPs rcp2.6, rcp4.5, rcp6.0 and rcp8.5), the suitability of the Natura 2000 network will be significantly reduced in most countries. Under the worst representative concentration pathways (rcp8.5), Austria, Sweden, and the Slovak Republic will have the highest percentages of potentially suitable habitats within their networks of protected areas, whereas suitable areas for $C$. calceolus disappear in many central and northern European countries (e.g., Estonia, Latvia, Lithuania, Hungary).

In Natura 2000 sites, populations of C. calceolus are usually restricted to specific areas. Table 4 lists the habitats that can ensure the survival of this species within the Natura 2000 network. Some populations of C. calceolus also occur in non-native spruce monocultures-commercial forest cultures which have replaced the original natural habi- 
tats. These populations are usually unprotected and are under exceptionally high threat by commercial forestry.

This section may be divided by subheadings. It should provide a concise and precise description of the experimental results, their interpretation, as well as the experimental conclusions that can be drawn.

Table 2. Factors that have been identified as threats for Cypripedium calceolus, by country.

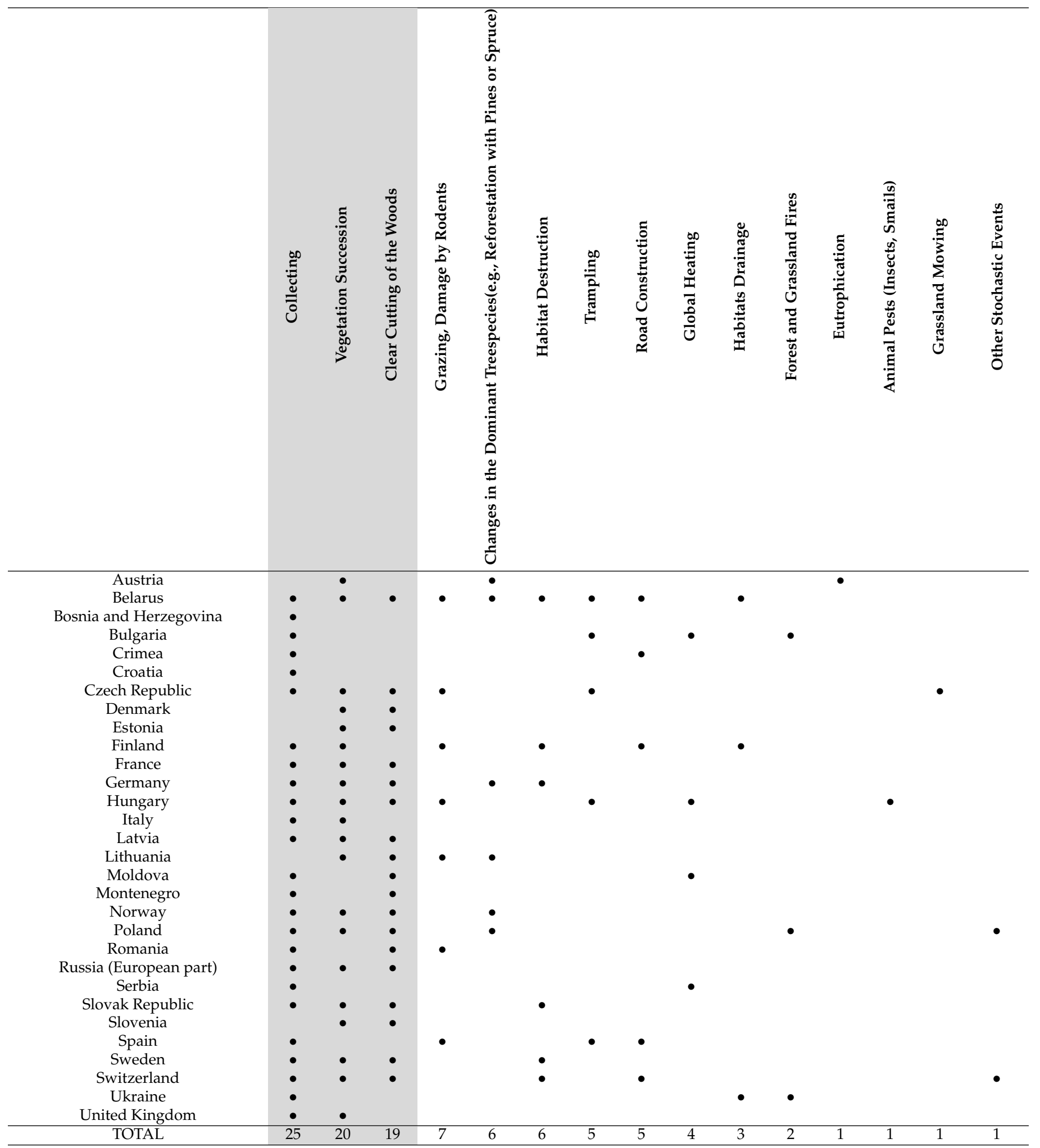




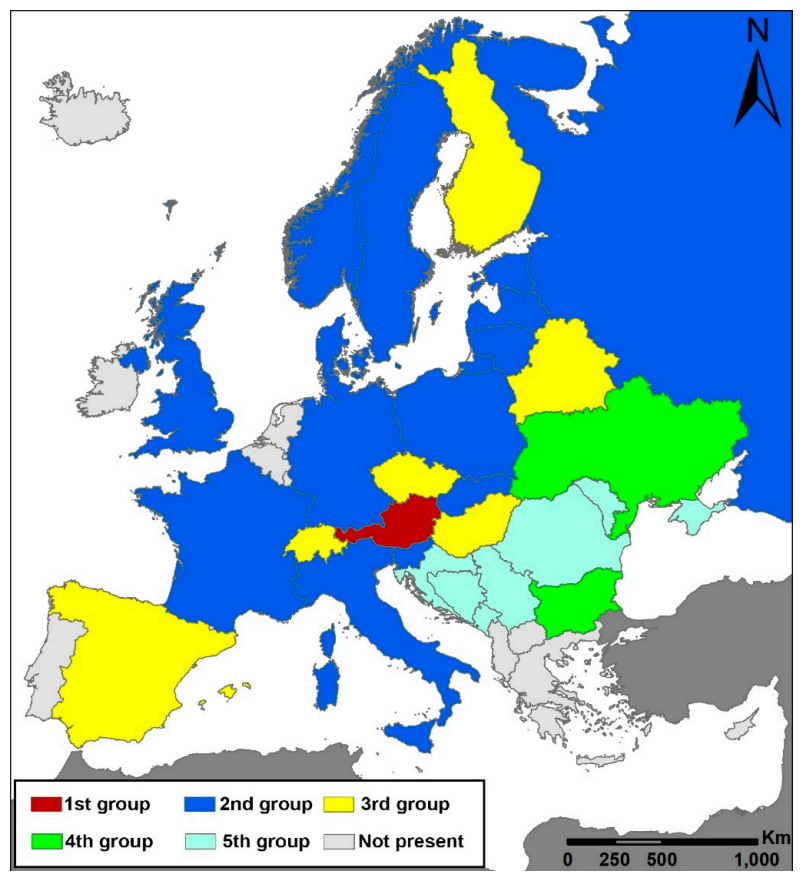

Figure 3. Groups of countries in which Cypripedium calceolus faces similar threats. The groups of countries have been identified on the basis of an unweighted pair-group method with arithmetic mean (UPGMA) cluster algorithm. The map was created using the projected coordinate system "Lambert_Azimuthal_Equal_Area".

Table 3. Numbers of $1 \times 1 \mathrm{~km}$ grid cells in the Natura 2000 network for each country, and percentage of potentially suitable areas for Cypripedium calceolus within the network. (RCP: representative concentration pathway).

\begin{tabular}{|c|c|c|c|c|c|c|}
\hline \multirow{3}{*}{ Country } & \multirow{3}{*}{$\begin{array}{l}\text { Grid Cells of the } \\
\text { Natura } 2000 \\
\text { Network }\end{array}$} & \multicolumn{5}{|c|}{ Potentially Suitable Area (\% of the Natura 2000 Network) } \\
\hline & & \multirow{2}{*}{ Current Climate } & \multicolumn{4}{|c|}{ Future Climatic Conditions (CCSM4) } \\
\hline & & & RCP2.6 & RCP4.5 & RCP6.0 & RCP8.5 \\
\hline Austria & 8638 & 89.65 & 55.14 & 43.45 & 43.49 & 29.88 \\
\hline Belgium & 2023 & 5.88 & 4.60 & 4.40 & 0.99 & 0 \\
\hline Bulgaria & 48,054 & 15.57 & 3.03 & 1.93 & 1.47 & 0.02 \\
\hline Croatia & 26,356 & 29.85 & 5.46 & 0.63 & 1.75 & 0 \\
\hline Cyprus & 1217 & 0 & 0 & 0 & 0 & 0 \\
\hline Czech Republic & 14,230 & 98.31 & 66.85 & 44.43 & 26.48 & 12.35 \\
\hline Denmark & 5868 & 74.63 & 61.71 & 34.99 & 54.93 & 19.07 \\
\hline Estonia & 9325 & 16.85 & 10.43 & 0.46 & 0 & 0 \\
\hline Finland & 53,579 & 2.61 & 4.90 & 2.85 & 2.47 & 4.97 \\
\hline France & 80,612 & 24.62 & 22.24 & 20.11 & 18.43 & 12.17 \\
\hline Germany & 59,599 & 65.65 & 34.95 & 26.84 & 27.13 & 10.29 \\
\hline Greece & 29,836 & 0.42 & 0.28 & 0.07 & 0.07 & 0 \\
\hline Hungary & 21,865 & 8.82 & 0.03 & 0 & 0 & 0 \\
\hline Ireland & 13,986 & 0 & 0 & 0 & 0 & 0 \\
\hline Italy & 47,610 & 23.84 & 18.13 & 16.56 & 17.46 & 13.49 \\
\hline Latvia & 1779 & 29.62 & 13.04 & 0.06 & 0 & 0 \\
\hline Lithuania & 11,170 & 59.30 & 20.67 & 13.05 & 0 & 0 \\
\hline Luxembourg & 738 & 89.02 & 57.32 & 70.05 & 58.67 & 12.87 \\
\hline Malta & 43 & 0 & 0 & 0 & 0 & 0 \\
\hline The Netherlands & 4813 & 9.27 & 26.01 & 15.62 & 11.68 & 0 \\
\hline Poland & 58,730 & 57.01 & 12.92 & 5.50 & 6.73 & 2.66 \\
\hline Portugal & 21,279 & 0 & 0 & 0 & 0 & 0 \\
\hline Romania & 67,318 & 47.65 & 30.95 & 22.23 & 21.25 & 8.61 \\
\hline Slovak Republic & 10,838 & 86.81 & 54.92 & 31.03 & 38.91 & 20.04 \\
\hline Slovenia & 11,137 & 62.37 & 28.64 & 21.06 & 14.62 & 9.26 \\
\hline Spain & 115,180 & 1.48 & 1.90 & 1.71 & 1.87 & 1.35 \\
\hline Sweden & 83,859 & 23.07 & 33.56 & 26.14 & 24.70 & 22.93 \\
\hline United Kingdom & 26,962 & 3.53 & 2.82 & 1.34 & 4.61 & 4.41 \\
\hline
\end{tabular}


Table 4. List of Natura 2000 habitats with Cypripedium calceolus sites in exemplary European countries.

\begin{tabular}{|c|c|c|c|c|c|c|c|c|c|c|}
\hline & bitat Type & $\begin{array}{l}\text { Alpine and } \\
\text { Subalpine } \\
\text { Grasslands }\end{array}$ & $\begin{array}{c}\text { Montane and } \\
\text { Xerothermic } \\
\text { Grasslands }\end{array}$ & $\begin{array}{l}\text { Alternately Wet } \\
\text { Meadows }\end{array}$ & Wet Screes & $\begin{array}{c}\text { Beech Forests } \\
\text { (Fertile, Calcified) }\end{array}$ & $\begin{array}{l}\text { Oak-hornbeam } \\
\text { Forests }\end{array}$ & $\begin{array}{l}\text { Ravine } \\
\text { Forests }\end{array}$ & $\begin{array}{l}\text { Riparian } \\
\text { Forests }\end{array}$ & $\begin{array}{c}\text { Thermofilous Oak } \\
\text { Forests }\end{array}$ \\
\hline \multicolumn{2}{|c|}{ Natura 2000 Code } & 6170 & $\begin{array}{l}6210 \\
6520\end{array}$ & 6410 & 8160 & $\begin{array}{l}9130 \\
9150\end{array}$ & 9170 & 9180 & 91E0 & 9110 \\
\hline
\end{tabular}




\section{Discussion}

\subsection{Conservation Status}

Despite Cypripedium calceolus being listed as a species of least concern in the IUCN Red List, with population trends described as stable at the global scale [9], we found that this species is classified as threatened (critically endangered, endangered, or vulnerable) in most European countries, where both the numbers and sizes of populations have decreased significantly over the last two decades. This could be attributed to the intensive environmental stress, habitat losses and fragmentation, small population sizes, etc., which caused a great reduction in its range. In Europe, C. calceolus is widespread but has undergone severe declines in the past, especially due to its collection by enthusiasts [9]. For example, according to Bilz [41], in the Czech Republic there are many localities but they are generally very small in size and the populations are fragmented, forming small scattered patches [35], whereas in Hungary, it occurs at no more than eight localities where it was formerly known from more than 20. This decrease has happened during the last century. The number of localities has remained constant over the last 10 years but the number of individuals has been continuously decreasing. Moreover, in Poland, there are historical records for over 200 localities in the lowlands, but most of them have been lost especially in western Poland. Similarly, in Norway, a population decline of $15-30 \%$ has been observed in the past and is assumed to continue in the future [1]. Generally, the populations are declining in parts of its range but are stable or increasing in other parts due to conservation measures that were taken [20]. The aforementioned arguments clearly demonstrate that conservation measures for the protection of $C$. calceolus at a pan-European level should be focused on its threat status at a country level. In this sense, the last IUCN global assessment of this species, which was conducted in 2014, cannot provide information of crucial importance regarding its regional status and threats. Moreover, as the specific assessment was based predominantly on data from Europe [9], we can suppose that lack of current data, as well as long-term monitoring data describing the situation in detail outside of Europe, are not available. This could also partly explain the imbalance between the conservation status of $C$. calceolus in Europe and worldwide. There is a high probability that there would be significant differences between its current status in different regions globally (e.g., Europe vs. Asia), as well as among the different European countries (e.g., southern vs. northern).

Differences can be discerned even between regions in a single country. In some cases, we found that the level of threat on a national scale may not correspond to the level in particular regions. For example, the species is considered nationally vulnerable in Poland, but has a higher threat level in seven out of 11 provinces e.g., [42,43]. It is identified as vulnerable and near threatened in two regions, and is absent in two other regional red lists. In several central and northern European countries, although the climatic conditions are suitable for C. calceolus (as well as for several other orchid species), the species has declined because of changes in land cover (e.g., deforestation, agricultural intensification) and in forest-management practices (e.g., changes in the dominant tree species, light conditions, density of shrubs) [44,45]. By contrast, in southern-European countries (e.g., Italy, Spain), C. calceolus is restricted to the northern parts of these countries, or to mountainous areas where the climatic conditions are suitable.

\subsection{Threats}

European countries differ not only in current Cypripedium calceolus conservation statuses but also in the major threats to this species [8] (Table 2). In Natura 2000 sites, populations of $C$. calceolus are usually restricted to specific areas. Table 4 lists the habitats that can ensure the survival of the species across the European Natura 2000 sites. It is worth noting that $C$. calceolus also occurs in other plant communities (see Appendix A) that were not intended for protection due to inconsistency with the description of the habitat in the Council Directive 92/43/EEC of 21 May 1992 on the protection of natural habitats and wild fauna and flora (Council Directive 92/43/EEC). In general, threats to the populations of $C$. calceolus can be divided into two basic groups: natural and anthropogenic. 
Natural factors include, for example, spring frosts, drought, or vegetation succession. Early-spring ground-level frosts can cause permanent, irreversible damage to C. calceolus inflorescences or to single flowers, and this problem is very harmful to populations growing in open meadows (compare those occurring within forests, where the minimum temperatures are always higher). This can be particularly significant towards the latitudinal or elevational limits of the species [46]. Drought events can also be harmful; Corkhill [47] noted that $C$. calceolus is sensitive to drought, and that young seedlings, especially, require constant moderate moisture. Although the aforementioned threats relate to the climatic conditions of sites where $C$. calceolus occurs, vegetation succession was classified as being among the most serious threats for this species in Europe. The disappearance of C. calceolus populations may be the result of the gradual overgrowth of trees, shrubs and herbaceous plants that occur at the sites. Based on our observations, C. calceolus populations in SW Poland are threatened by Crataegus L. spp., Rubus fruticosus L., Aegopodium podagraria L., and Fraxinus excelsior $\mathrm{L}$. Such changes in the vegetation cover affect light conditions, which in turn significantly affect the viability of $C$. calceolus populations. Previous research has shown that reduction of light intensity caused by forest overgrowth can lead to an extension of the dormant period and postponement of the flowering period of this species [48].

Anthropogenic factors are usually stronger and may have fatal consequences. According to the IUCN, major threats to this species are habitat destruction, agriculture intensification, ecosystem modification, and inappropriate forest management (such as clear cutting, logging, and wood harvesting, use of herbicides and pesticides, equipment use that can severely compact the soil, agricultural and forestry effluents, road and trail construction), as well as collecting from the wild [9]. Collecting, reported as a major threat in as many as 25 European countries, is inexcusable in the 21st century, but digging and replanting into gardens unfortunately still occurs. In this way, unique meadow populations are destroyed-for example, the population in the 'Babylon' meadow in the eastern Sudetes (SW Poland) was irretrievably destroyed in 2016. It is hard to believe that specimens of C. calceolus, an iconic species protected by both national and international laws, are still being collected for private gardens and for herbaria. Burning of meadows and grasslands may also be one of the key factors in destroying the structure of the population and in limiting the range of the species at a regional scale. Other factors affecting the species habitats should also be taken into account, such as digging (meant here as intentional destruction, not related to collecting) and landslides caused by erosion as a result of human activity or natural disasters like drought, floods and hurricanes, which were described as stochastic events (Table 2).

Specific forest-management practices can severely threaten C. calceolus [41]. Among such practices, clear-cutting of woods threatens C. calceolus populations in many countries. Large-scale deforestation, especially when the dominant and native tree species are replaced, is a controversial practice that is widely applied in commercial forestry in many European countries. One of the largest $C$. calceolus populations in the SW Poland was destroyed as a result of clear-cutting in 2017, on state property, and compensation was considered unnecessary. On the other hand, clear cutting in the species' localities is prohibited in some countries (e.g., Slovenia, Italy), and others will follow soon as the result of a new EU Forest Strategy [49]. Following national and EU legislation, local regulations for forest management should be applied in protected areas and in Natura 2000 sites in all EU countries. In particular, data from official C. calceolus monitoring should be updated and made available as open-access.

\subsection{Conservation Strategy}

Only after the commencement of detailed studies on Cypripedium calceolus does the regional conservation status of its populations have a chance of being improved. It is necessary to protect habitats and micro-sites where this species occurs, and to map its actual distribution, in particular by searching old-growth forests with a predominance of beech, but also in oak-hornbeam forests and other plant communities suitable for the 
species (Table 4, Appendix A). Since C. calceolus has a wide ecological latitude and is not confined only to one specific plant community, it is worth establishing co-operation with foresters who usually have knowledge of the locations of the most valuable plant species. Historical data should also be analyzed, as there are instances of the rediscovery of numerous C. calceolus populations, even after as long as 80 years [34]. Ultimately, it is necessary to check regularly all known populations of the species, including those that survive in conifer plantations and on private land. Accordingly, a list of both recommended and inappropriate conservation measures is presented in Table 5, based on data collected concerning practices that focus on the protection of the species.

Table 5. Conservation strategy for Cypripedium calceolus.

\begin{tabular}{ll}
\hline \multicolumn{1}{c}{ Protective Actions for Natural Populations of Cypripedium calceolus } \\
\hline - & \multicolumn{1}{c}{ Recommended } \\
\hline - & $\begin{array}{l}\text { Mabitat protection } \\
\text { Database with detailed information on the species habitat and population (including genetic } \\
\text { structure) }\end{array}$ \\
- $\quad \begin{array}{l}\text { Exchange of knowledge between experts and standarization of protection procedures in all } \\
\text { - }\end{array}$ \\
Integration of the national areas hosting populations of Cypripedium calceolus in the \\
European network for this species to exchange of information and cooperation for using the \\
best techniques and strategies conservation, as well as in order to obtain funds for the \\
elaboration conservation plan \\
Education of local residents in the importance of the species protection \\
Ex situ conservation
\end{tabular}

\section{Inappropriate}

- Implementation of protective or economic activities without environmental supervision

- Determination of protective measures by unskilled persons

- $\quad$ Ignoring the possible occurrence of species in a poorly explored area

- $\quad$ Publishing of Global Positioning System (GPS) coordinates of Cypripedium calceolus population

A key finding of the present study is the degree of effectiveness of the Natura 2000 network across the EU countries. Northern and/or mountainous countries present the highest percentages of potentially suitable areas within the Natura 2000 network. Finland and the United Kingdom constitute two exceptions to this rule. The lower habitat suitability of the networks of these two nations could be attributed to the sampling bias of the species records used to build their models [15]. This might be also be the case for other countries where the species is absent (e.g., Belgium, the Netherlands).

The fact that, under future climatic conditions, C. calceolus is expected to decline in several countries in which healthy colonies currently exist clearly demonstrates that appropriate conservation actions should be applied for its survival. Such actions should include appropriate management of the sites where C. calceolus is present (e.g., restrictions on clear-cutting, control of vegetation succession; [45], improvement of site conditions where the species was recorded in the past, and establishment of seedlings or young plants [50].

However, it might be hypothesized that the predictions of Kolanowska and JakubskaBusse [15] are only indicative of the actual distribution of C. calceolus. This could be attributed to the environmental predictors used by Kolanowska and Jakubska-Busse [15], as well as to the spatial resolution of the analyses. Although Kolanowska and JakubskaBusse [15] exclusively used bioclimatic variables to build their models, for such a wide distribution area (i.e., Europe) this is not a restriction. This is because species distributions 
at broad geographical scales are mainly driven by climatic factors [51], while the inclusion of land-cover variables in bioclimatic models does not improve their predictive accuracy, according to Thuiller et al. [52]. By contrast, it is known that plant species can occur in micro-sites with suitable environmental conditions (e.g., microclimate, vegetation, soil factors) that cannot be predicted as suitable using a coarser spatial resolution [53].

It is well known that the results of species-distribution models can be used to guide field surveys in order to find populations of known or rare species and to set conservation priorities (for more information see [54]). Field surveys towards areas of higher habitat suitability are very important in recording new populations of rare species. This is especially true for orchids, whose distributions are affected not only by abiotic factors, but also, for several species, by the distribution of other organisms (pollinators, mycorrhizal fungi; $[16,55]$ ). Moreover, conservation actions might be focused on those areas where greater possibilities for the future existence of selected species are observed.

Observations of $C$. calceolus from various countries indicate its limited occurrence, and the need to develop effective methods of protection [56]. The species maintains populations under certain habitat conditions, but different population sizes and plant communities each require a special approach and uses of different conservation measures; each population should, therefore, be treated individually. The human influence on species is generally negative, manifested by actions that have led to the decline of populations in many European countries. The actions undertaken are usually limited to passive protection, until the destruction of individuals due to natural or anthropogenic factors. For the effective protection of C. calceolus in Natura 2000 sites, the participation of experts in botany, including orchid biology, is necessary at several stages. Their participation is a requirement for the assessment of resources, habitat conditions, threats, and protective actions in each Natura 2000 site where C. calceolus is found. The results should lead to further activities at the regional scale, including the shaping of ecosystems (usually aimed at improving the condition of the Natura 2000 habitats) and implementation of necessary legal actions. Populations of the species are difficult to protect due to its complex biology and, while listed in Annex II of Council Directive 92/43/EEC, it requires special attention in terms of forestry. Since the conservation potential of $C$. calceolus varies by country, there is no comprehensive management system for this species. Based on experience gained, directions for the protection of C. calceolus leading to the best protection of its population were developed, presented in Figure 4.

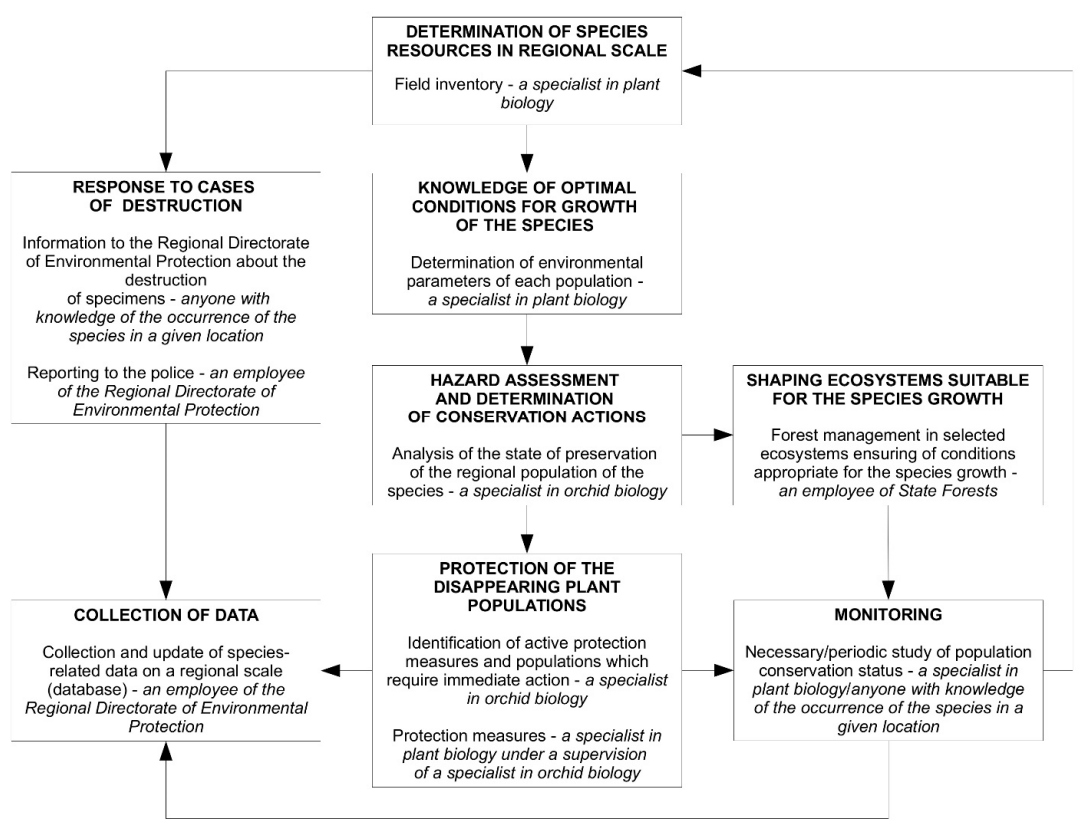

Figure 4. Proposed protective-action directions of Cypripedium calceolus populations on a regional scale. 


\section{Conclusions}

The key role of scientists is in the identification of plant communities and of optimal environmental conditions in which Cypripedium calceolus grows. This should be a guideline for those entities responsible for the management of areas where this species is found. It is necessary to develop methods and to implement a pattern of handling the occurrence of C. calceolus because, in many European countries, this is still a minor issue compared to, e.g., the amount of wood that must be obtained from the forest in which the species grows. Projects for regional conservation of this species, developed by scientists with financial support from the region's authorities (involving all stakeholders-e.g., forest owners, managing companies, local communities), can save many C. calceolus populations and enhance their viability, starting from a detailed inventory, risk assessment, development and implementation of protective measures, and further observations (Figure 4). In any case, comprehensive efforts must be made to maintain the ecosystems in which lady's slipper grows or could grow. Actions undertaken by foresters should not be irreversible but cyclical, in close co-operation with scientists. Monitoring activities [57] will allow to a better understanding of the threats affecting the species and population dynamics. This information will be of great help for the possible implementation in the future of in situ and/or ex situ conservation actions $[57,58]$ allowing for effective species protection at the regional level.

Updating the global occurrence, current conservation status, and demography of Cypripedium calceolus populations will also play an important role in the protection of this orchid species. Failure to update the chorological data, or the introduction of imprecise data, distorts our knowledge of the actual state of its population, and may make it difficult to conduct effective protective measures.

Author Contributions: Conceptualization, A.J.-B., M.Ś.; data collection was performed by A.J.-B., S.T., M.Ś., Z.K., V.D., C.S., M.K., P.E., S.H., P.L. and K.K.; formal analysis, A.J.-B., S.T., M.K.; writingoriginal draft preparation, A.J.-B., S.T., M.Ś. and Z.K.; writing—review and editing, A.J.-B., S.T. and M.S. All authors have read and agreed to the published version of the manuscript.

Funding: This work was supported by the Ministry of Education, Youth and Sports of CR within the CzeCOS program, grant number LM2018123. Vladan Djordjević, PhD was supported by the Ministry of Education, Science and Technological Development of the Republic of Serbia (number 451-03-68/2020-14/200178).

Institutional Review Board Statement: Not applicable.

Informed Consent Statement: Not applicable.

Data Availability Statement: The data presented in this study are available on request from the corresponding author.

Acknowledgments: We would like to thank prof. Maxim A. Dzhus (Belarusian State University), Myroslav Shevera, PhD (National Academy of Sciences of Ukraine), Mindaugas Lapele, PhD (Dzukija National Park, Lithuania), Michele Lussu, PhD (Italy), Tiiu Kull, PhD (Estonia), Vedran Šegota (Croatia), Janez Mihael Kocjan (Slovenia) for providing data and information for C. calceolus. We also thank Ian Howarth (Rickmansworth, UK) for improving the text.

Conflicts of Interest: The authors declare no conflict of interest.

\section{Appendix A}

Habitats and communities of Cypripedium calceolus in different regions of Europe Appendix A.1. Bulgaria

In Bulgaria, it inhabits mixed forests and Pinus nigra subsp. pallasiana forests. The forest phytocoenoses are formed by 120-year-old trees dominated by Pinus nigra and an admixture of Abies alba and Fagus sylvatica. In the shrub layer, undergrowth is created by the above species of trees, while underbrush consists of Tilia platyphyllos, Acer hyrcanum, Fraxinus ornus, Sorbus torminalis, Cornus mas, Lonicera coerulea, Daphne mezereum, Rubus saxatilis 
and Clematis vitalba. The grass layer is dominated by Calamagrostis arundinacea, with a significant share of Pteridium aquilinum, Lilium martagon, Cephalanthera longifolia, Corallorhiza trifida, Polygonatum odoratum, Aremonia agrimonoides, Cardamine bulbifera, Clinopodium vulgare, Euphorbia amygdaloides, Fragaria vesca, Potentilla regis-borissii, Mycelis muralis, Helleborus odorus, Primula veris, Hieracium murorum, Pyrola chlorantha, Salvia glutinosa, Sanicula europaea, Viola odorata, etc. There are also seedlings of Fagus sylvatica, Acer hyrcanum and patches of mosses [59].

\section{Appendix A.2. Crimea}

In total, 15-20 localities in the Crimea were known, but all clustered rather locally in the Western part of the Crimean Mountains; currently the species is known from only one site on Boyka Mountain near Sokolinoye. Ecologically, it grows (or was growing) in Crimea in beech forests often mixed with hornbeam (Carpinus), usually near stream banks at 500-1100 $\mathrm{m}$ a.s.1. [12,60].

\section{Appendix A.3. Croatia}

In this country Cypripedium calceolus was found on Velebit Mt, Bilogora Mt, Kalnik Mt, Žumberak Mt, in Gorski Kotar, Plitvice Lakes National Park, Krbava, and at Plješevica Mt, inhabiting most commonly Fagus sylvatica forests, especially the community Fagetum croaticum australe $[24,61,62]$. Recent studies on the Velebit mountain range indicated that C. calceolus grows at the edge of a beech forest together with the following species: Astrantia major, Cardamine enneaphyllos, Dryopterix filix-mas, Maianthemum bifolium, Neottia nidus-avis, Paris quadrifolia, Polypodium vulgare, Pulmonaria officinalis, Sanicula europaea and Symphytum tuberosum; in subalpine beech forests on sites of northern aspect together with Astrantia major, Cerastium dinaricum, Dryas octopetala, Primula kitaibeliana and Aethionema saxatile, as well as in mixed forests of Fagus sylvatica and Abies alba, with the following accompanied taxa: Acer pseudoplatanus, Anthriscus nitidus, Astrantia major, Geranium phaeum and Picea abies [62]. Furthermore, Nikolić and Topić [63] noted that C. calceolus occurs in Illyrian low-montane acidocline fir-beech forests (code 41.1C221) and Illyrian low-montane neutrophile fir-beech forests (code 41.1C222).

\section{Appendix A.4. Czech Republic}

Recently there are about 80 locations of Cypripedium calceolus in the Czech Republic (www.biomonitoring.cz, accessed on 18 January 2021). They are located in lowlands, hills, foothills of termophytic, mesophytic and oreophytic regions of the country, i.e., all geographic regions except the Moravskoslezský, Plzeňský and Karlovarský region (for a map of distribution see www.pladias.cz, accessed on 18 January 2021).

This species usually grows in light forests and their edges, but some populations also survive in cultural spruce forests [64,65]. Oak-hornbeam forests, thermophiles oak forests, herb-rich beech forests and rarely also ravine forests are the most common habitats of this species [35]. However, it also occurs on non-forest habitats - in the humid variations of broad-leaved grasslands and in alternately wet Molinion meadows. C. calceolus is as a taxon mainly growing in forest borders and canopy gaps including forest roads, fallen trees areas, fires and clearings. It is usually found in forests with sparse herbaceous undergrowth.

\section{Appendix A.5. Germany}

The species occurs in Germany from the Baltic Sea coast to higher altitudes in the Bavarian Limestone Alps. In Northeast Germany, the remaining populations are extremely threatened with extinction. The once individual occurrences on the Jasmund Peninsula on Rügen are now close to extinction. Here the species occurred in the chalk coast in orchid beech forests. Another remaining occurrence in Brandenburg consists of only a few sterile individual plants [66]. Size and stable occurrences only exist in central and southern Germany. Occurrences with several thousand individuals can still be found in Lower Saxony, Thuringia, Bavaria and Baden-Württemberg, but numerous occurrences only consist of small populations and individual plants. Kretzschmar [67] calculated an absolute decrease of $57 \%$ of the occurrence for Central Germany. In the meantime, 
however, the situation in many regions is likely to have deteriorated dramatically. As part of targeted protective measures (e.g., LIFE+ project "Diversity on limestone" in North Rhine-Westphalia [68], occurrences of Cypripedium calceolus were also stabilized and growth conditions improved again. In Germany, C. calceolus is a kind of semi-shady, grass and herb rich, often also moss-rich, more or less light deciduous and coniferous forest sites [38].

Appendix A.6. Poland

Cypripedium calceolus is a plant species, which is generally not attached to a specific habitat or plant community. In the Polish lowlands, it prefers forest habitats of varying degrees of preservation, but it also occurs in the forest edge communities, like thickets and roadsides. In highlands and mountainous conditions, it is known from grasslands, usually partially shaded with trees or bushes. C. calceolus habitats are characterized by good light availability and a high content of calcium carbonate in the substrate. The species most often grows on rendzinas consisting of dolomites, limestones and marls, rarely on brown soils, black molds and alluvials, in lowlands it was also observed on boulder clays. In upland areas, the species grows on moist soils, characterized by an undertone of water rich in calcium carbonate, on gentle slopes it occurs on shallow soils, with present stony fraction and even rock rubble. In mountainous regions, it inhabits steep slopes on shallow humus rendzinas, formed on heavy clays. If it grows in forest communities, the plants are characterized by a relatively lax inflorescence. It is observed not only in 120- to 150-year-old forests, but also in 40- to 50-year-old woodland, and in forest gaps created due to cutting. Less often it is found in open areas, usually in the vicinity of open undergrowth of trees or shrubs [34].

In climatic and geographical conditions in Poland, C. calceolus occurs mostly in forest areas characterized by beech and oak stands, with an admixture of hornbeam, ash, linden, maples, as well as spruce, larch, pine and sometimes yew [34]. It is also found in birch, pine and spruce plantations on beech or fertile oak-hornbeam habitats [34]. It is usually observed at the edges of forests, where it grows alongside roads. In the undergrowth of fertile oak forests, it is most often accompanied by: Anemone nemorosa, Asarum europaeum, Daphne mezereum, Epipactis helleborine, Galeobdolon luteum, Galium odoratum, Hedera helix, Melica nutans, Viola reichenbachiana and Viola mirabilis, while in fertile beech forests, it grows in vegetation patches with: Aquilegia vulgaris, Carex digitata, Carex montana, Hypericum montanum, Lathyrus niger, Lilium martagon, Polygonatum odoratum, Pyrola rotundifolia, Pyrola secunda, Sanicula europaea and Vincetoxicum hirundinaria [69,70]. In "orchidaceous" beech forests, it is also accompanied by: Cephalanthera damasonium, Cephalanthera rubra, Corallorhiza trifida, Epipactis helleborine and Neottia nidus-avis. To date, several forest associations with confirmed occurrence of Cypripedium calceolus have been identified in Poland, which are: Potentillo albae-Quercetum (Quercetalia pubescenti-petraeae order), Stellario-Carpinetum, Galio-Carpinetum, Tilio-Carpinetum (Carpinion betuli alliance), Carici albae-Fagetum, Dentario enneaphyllidis-Fagetum, Fagus sylvatica-Hypericum maculatum (also described as Taxo-Fagetum) and Fagus sylvatica-Cypripedium calceolus (Fagion sylvaticae alliance), the last of which was identified as a unique humid calcareous beech forest, known from only one site in the country. In terms of beech forests, associations with C. calceolus were not always identified, but were generalised at level of sub-alliances: Galio odoratiFagenion, Cephalanthero-Fagenion or Dentario glandulosae-Fagenion (Fagetalia sylvaticae order). The occurrence of $C$. calceolus was less frequently documented from mixed coniferous communities: Querco-Pinetum and Serratulo-Pinetum (Dicrano-Pinion alliance) [14,71]. Rarely, C. calceolus can be observed in thickets and shrub communities developed on calcareous substrates, e.g., hazel or beech bushes, assorted with various tree and shrub species. It also grows in thickets and thermophilous saum communities [44]. To date, only few shrub communities with $C$. calceolus have been identified, like: Peucedano cervariae-Coryletum (Potentillo albae-Quercion alliance) and the community with Eupatorium cannabinum (Atropion belladonnae alliance). Occurrence of the species in the communities of Trifolio-Geranietea sanguinei class was also mentioned, but not fully described [44]. 
Cypripedium calceolus rarely occurs in areas with high sun exposure, as xerothermic grasslands [34,72] and calcareous high mountain grasslands, where it creates sometimes stable populations. It is noteworthy that $C$. calceolus may be accompanied there by other rare orchids, like: Epipactis atrorubens, Epipogium aphyllum, Gymnadenia odoratissima, Corallorhiza trifida and Orchis mascula. So far, only two grassland communities with occurrence of C. calceolus have been specified: Onobrychido-Brometum (Bromion erecti alliance) and Carici sempervirentis-Festucetum tatrae (Seslerion tatrae alliance) [34].

\section{Appendix A.7. Romania}

Cypripedium calceolus is considered a rare species in Romania. In the past in Romania C. calceolus was reported in many sites in almost 100 localities and most of them located from the lowland to the high mountain region. In 1972, the main flora of Romania at that time mentioned 98 localities of C. calceolus [73].

In recent years the populations of Cypripedium calceolus have been greatly restrained. The often situations encountered in the recent years are the fact that some of the locations cited in the Romanian flora were repeatedly revisited but the plants were not found again and if the population still exists it is represented by only a few plants or getting smaller each year with only few flowering specimens $[37,74,75]$. However, in the "Synthetic report concerning the state of conservation of species and habits of community interest from Romania" the general assessment of the state of conservation for C. calceolus is considered favorable with unknown tendency [76]. C. calceolus is cited as a criterion species for the declaration of Natura 2000 sites and, according to Article 17 of the Council Directive 92/43/EEC, the Government must periodically report its conservation status to the European Environmental Agency. The report was sent by Romania for the period 2007-2012 and submit the presence and the conservation status of C. calceolus in the Natura 2000 Network in a $10 \times 10 \mathrm{~km}$ grid cells. The conservation status was assessed as favorable by our country [76].

European University Information Systems (EUNIS) data for Romania shows 21 Natura 2000 sites with C. calceolus, just four sites located in the lower lands and most of them located in the upland regions.

As note of hope for so many lost locations some recent publications have been confirmed the presence of $C$. calceolus in another lower land areas that are not mentioned in the EUNIS database. Two populations of $C$. calceolus have beeninvestigated in the central area of Romania, near Sovata (Mures county) in Ursu Lake Reservation and Sărături Arboretum near Sovata at an altitude of $530 \mathrm{~m}$. The ecocenotic environment for the species is a phytocenoses of the Carpino-Fagetum association. Other characteristic species for this area are: Acer campestre, Rubus hirtus, Sambucus nigra, Sanicula europaea, Lathyrus hallersteinii, Neottia nidus-avis, Lathyrus vernus, Festuca heterophylla, Galium schultesii, Ranunculus auricomus, Brachypodium sylvaticum, Pulmonaria officinalis, Galium odoratum, Salvia glutinosa, Actaea spicata, Mycelis muralis, Athyrium filix-femina, Anemone nemorosa [37].

In 2016 in the northern part of Romania in a Natura 2000 site, Făgetul Clujului-Valea Morii (Cluj county), after more than 80 years since the last record in this region a new population of $C$. calceolus was discovered. One population is located at the edge of a small forest opening between Galio-Carpinetum oak-hornbeam and Dacian oak-hornbeam forests and another along the Asperulo-Fagetum beech forest, a transition area between the forest and a dry calcareous grassland habitat at $486-500 \mathrm{~m}$ altitude. The average of tree age is 55-60 years. The floristic composition communities identified are: Carpino-Fagetum, Lathyro hallersteinii-Carpinetum Coldea and Carici montanae-Quercetum petraeae. Other characteristic species for this area are: Aposeris foetida, Lathyrus hallersteinii, Carex montana, Pulmonaria mollis, Carex pillosa, Galium schultesii, Festuca drymeia, Hepatica nobilis, Sanicula europaea, Cephalanthera longifolia, Salvia glutinosa, Gymnadenia conopsea, Staphylea pinnata, Genista tinctoria etc. [74].

In 2017 in Tudora Reservation (Botosani county), with an altitudinal range from 314 to $513 \mathrm{~m}$, a population of $C$. calceolus was confirmed in an association belonging to the Geranio robertianae-Fagetum taxetosum baccatae, Dacian Beech forests (Symphyto-Fagion). 
Other northern populations are mentioned near Suceava (Neamt county) are in a habitat consisted by mixed wood forest of beech and oak. The vegetal associations are Geranio robertianae-Fagetum and Galio schultesii-Fagetum at 390-410 m altitude [75].

Data regarding habitat and social communities where C. calceolus is reported from upland areas are from more open land in mountain hay meadows. One investigated population is located in the Piatra Craiului Mountains (Rucăr village area) in a meadow within a mesophilic pasture near the forest areas characterized by spruce (Picea abies). The vegetal association belongs to Anthoxantho-Agrostetum capillare, characteristic classification of NATURA 2000 habitat 6520 mountain hay meadows. In this location C. calceolus is accompanied by Trollius europaeus, Fragaria vesca, Alchemilla vulgaris, Anthyllis vulneraria, Trifolium montanum, T. repens, T. pratense, Lotus corniculatus, Linum catharticum, Carum carvi, Astrantia major, Laserpitium latifolium, Pimpinella saxifraga, Heracleum sphondylium, Polygala amara, Gentiana asclepiadea, G. cruciata, Pedicularis comosa, Rhinanthus rumelicus, G. cruciata, Thymus balcanus, Phyteuma tetramerum, Centaurea pseudophrygia, Listera ovata, Orchis morio, Neottia nidus-avis, Gymnadenia conopsea, Platanthera bifolia, Briza media, Dactylis glomerata, Agrostis capillaris, Anthoxanthum odoratum, Trisetum flavescens etc. [77].

\section{Appendix A.8. Russian Federation}

The territory of Russian Federation covers some of the largest portions of the total Cypripedium calceolus distribution area in Europe, extending from $42^{\circ} \mathrm{N}$ to $69^{\circ} \mathrm{N}$ latitudinally, and longitudinally almost throughout. Ecologically C. calceolus occupies a wide range of habitats, depending on climatic zone. It tolerates wide range of insolation, varying from deep shade (5-7\%) to full sun; similarly, it tolerates wide range of soil humidity, but permanently grows on basic soils, probably everywhere [60,78]; it is accustomed to low soil $\mathrm{pH}$ in the northern part of its distribution area, whereas southwards, this amplitude is possibly wider.

The northernmost population of $C$. calceolus in Russia, which is located in Murmansk Region, occurs in light shade (30-50\%), in the podzol, peaty podzol or peaty soil [79]; one of populations in Murmansk Region, which was subjected for a detailed study for years, was located in pine forest with Betula pubescens, Salix caprea, Juniperus sibirica, herb layer consisted of Cirsium heterophyllum, Bartsia alpina, Potentilla erecta and other species [79].

In NE and NW Regions of Russia, where C. calceolus may be locally numerous in especially favourable conditions, its habitats are described as 'spruce, birch, and aspen forests, forested swamps, calcium outcrops' in the Komi Region [80]; 'grass-swamp and grassy forests composed with various tree species, afforested eutrophic swamps' in the Karelia Region [81]; and 'hill slopes in various extend covered by woody vegetation, river slopes, edges of forests and forest glades, wet boggy forests on carbonate soils, old limestone quarries' in the Leningrad, Pskov and Novgorod Regions [82]. Thus, in this area ecologically discussed species is rather variable, and the number of its localities in this area is sometimes numerous as well.

If we go further south, the ecology of C. calceolus is repeatedly described by a combination of similar habitats, although the density of the populations may reduce. Examples: 'spruce, spruce-broadleaved and broad-leaved forests in the edges of river valleys and ravines, usually in the places where limestone is situated near to the surface of the ground' in the Vladimir Region [83]; deciduous, coniferous or coniferous-broadleaved forests, edges of swamps' in the Kaluga Region [39]).

Near to southern species limit, C. calceolus is usually recorded only in the shady forests: 'dark forests' in Tambov Region [84]; 'pine-broad-leaved forests on carbonate soil' in Samara Region [85]; probably, near to the southern limit, in the areas with more arid climate, this species finds favourable conditions in the narrow amplitude of habitats. In four to five southernmost regions of European Russia (Rostov, Volgograd, Astrakhan and Kalmykia Regions), C. calceolus is absent. Its presence in the Voronezh Region is uncertain.

In the eastern part of the country, C. calceolus is reported predominantly either from forests or bogs. In the Perm' Region it was reported from 'coniferous and deciduous forests, boggy spruce forests, on calcareous slopes' [86]; in the Bashkortostan Region 'in forests of 
different composition ( ... ), on forest edges, at the marginal parts of afforested bogs' [87]. Thus, here we see generally the same amplitude, with the one possible exception that it less often inhabits places with a higher level of insolation.

Interestingly, the influence by large wild animals was reported as having influence on the distribution and spread of this species. It is widely known that many ephemeral tuberous orchids with a short life cycle depend on soil disturbance. It is remarkable that the same was noted for $C$. calceolus with its long-life cycle: 'positive influence was noted during the period of increase of the number of boars, who were losing the soil, thus contributing to an increase in successful seed germination' [38].

Appendix A.9. Serbia and Montenegro

In Serbia, Cypripedium calceolus was found in the community Arctostaphylo-Piceetum [88], whereas in Montenegro it occurs in the Pinus nigra forests [89].

\section{Appendix A.10. Slovenia}

In Slovenia, Cypripedium calceolus occurs mainly in different beech forests communities: Ostryo-Fagetum, Arunco-Fagetum, Rhododendro hirsuti-Fagetum, Anemono trifoliae-Fagetum, Homogyno sylvestris-Fagetum, Omphalodo-Fagetum and Polysticho lonchitis-Fagetum, and other communities, such as: Petasiti paradoxi-Piceetum, Brachypodio-Pinetum sylvestris, Alno incanaePinetum sylvestris, Lamio orvalae-Alnetum incanae, Aceri-Alnetum incanae, Adenostylo glabraePiceetum, Rhodothamno-Pinetum mugo, Amelanchiero ovalis-Pinetum mugo, Rhododendro hirsutiBetuletum carpaticae, Rhodothamno-Laricetum, Astrantio carniolicae-Adenostyletum glabrae and Caricetum ferrugineae s.1. [39,90,91].

\section{Appendix B.}

Table 1. The IUCN threat category of Cypripedium calceolus for all European countries.

\begin{tabular}{cccc}
\hline Country & IUCN category & IUCN Criteria & References \\
\hline Greece & EX & - & {$[92,93]$} \\
\hline Bulgaria & CR & B1ab(v)c+2ab(v); C1+2a(i,ii); D & {$[94]$} \\
\hline Serbia & CR & B2dC2b & {$[89]$} \\
\hline Croatia & EN & A4a, A4d & {$[24,61,63]$} \\
\hline Bosnia and Herzegovina & CR & Not evaluated & {$[95]$} \\
\hline Montenegro & EN & D & {$[96]$} \\
\hline Romania & VU & B2ab(i,ii,iii) & {$[97-99]$} \\
\hline Poland & VU & B2ab(i, ii, iii, iv) & {$[14,26]$} \\
\hline France & VU & A4acd & {$[100,101]$} \\
\hline Italy & LC & - & {$[102-104]$} \\
\hline Estonia & NT & Not evaluated & {$[105]$} \\
\hline UK & CR & D & {$[106,107]$} \\
\hline Spain & EN & C1 & {$[108,109]$} \\
\hline LC & CR & Evaluation & {$[110]$} \\
\hline Russia $($ only for C. calceolus $)$ & VU & B1ab(i,ii,iv,v) $+2 a b(i, i i, i v, v) ; C 2 a(i, i i) ; D . ~$ & {$[111,112]$} \\
\hline Crimea & VU & Evaluation A2a+B2ab(i, ii, iii, iv) & {$[113]$} \\
\hline Germany & & C1 & {$[114-116]$} \\
\hline
\end{tabular}


Table 1. Cont.

\begin{tabular}{|c|c|c|c|}
\hline Country & IUCN category & IUCN Criteria & References \\
\hline Slovak Republic & NT & - & {$[117,118]$} \\
\hline Belgium & EX & - & [6] \\
\hline Luxemburg & EX & - & [6] \\
\hline Ukraine & EN & Not estimated & {$[10,28,29]$} \\
\hline Switzerland & VU & B2ab(iii) & [119] \\
\hline Austria & NT & - & [120] \\
\hline Slovenia & VU & Not estimated & {$[10,121,122]$} \\
\hline Hungary & $\mathrm{EN}$ & Not estimated & {$[123,124]$} \\
\hline Moldova & $\mathrm{CR}$ & D- & {$[10,125]$} \\
\hline Belarus & VU & Not estimated & [10] \\
\hline Lithuania & VU & Not estimated & {$[10,126]$} \\
\hline Norway & NT & - & [127] \\
\hline Latvia & VU & Not estimated & {$[128,129]$} \\
\hline Sweden & $\mathrm{LC}$ & - & [130] \\
\hline Finland & NT & A2ab, B2b(iii) & [131] \\
\hline Denmark & VU & D2 & {$[132,133]$} \\
\hline Liechtenstein & EX & - & [10] \\
\hline The Netherlands & EX & - & [8] \\
\hline
\end{tabular}

\section{References}

1. Sundseth, K.; Creed, P. Natura 2000: Protecting Europe's Biodiversity. Office for Official Publications of the European Communities; European Commission, Directorate General for the Environment. Information Press: Oxford, UK, 2008; p. 296.

2. Del Prete, C.; Mazzola, P. Endemism and speciation in the orchids of Mediterranean Islands. Ecol. Mediterr. 1995, 21, 119-134. [CrossRef]

3. Bilz, M.; Kell, S.P.; Maxted, N.; Lansdown, R.V. European Red List of Vascular Plants; Publications Office of the European Union: Luxembourg, 2011; p. 144.

4. Hultén, E.; Fries, M. Atlas of North European Vascular Plants: North of the Tropic of Cancer I-III; Koeltz Scientific Books: Oberreifenberg, Germany, 1986; p. 1172.

5. Averyanov, L.V. The genus Cypripedium (Orchidaceae) in Russia. Lindleyana 2000, 15, 197-221.

6. Kreutz, C.A.J. The Orchids of Europe, North Africa and the Near East. A Fieldguide; Kreutz Publishers: Landgraaf, The Netherlands, 2021.

7. Nemer, W.; Rebbas, K.; Krouchi, F. Découverte de Cypripedium calceolus (Orchidaceae) au Djurdjura (Algérie), nouvelle pour l'Afrique du Nord. Fl. Medit. 2019, 29, 207-214. [CrossRef]

8. Terschuren, J. Action Plan for Cypripedium calceolus in Europe; Council of Europe Publications: Strasbourg, Germany, 1999; p. 27, Nature and environment, No 100.

9. Rankou, H.; Bilz, M. The IUCN Red List of Threatened Species. Available online: http:/ / dx.doi.org/10.2305/IUCN.UK.2014-1.RLTS T162021A43316125.en. (accessed on 15 February 2021).

10. Kull, T.; Selgis, U.; Pecinã, M.V.; Metsare, M.; Ilves, A.; Tali, K.; Sepp, K.; Kull, K.; Shefferson, R.P. Factors influencing IUCN threat levels to orchids across Europe on the basis of national red lists. Ecol. Evol. 2016, 6, 6245-6265. [CrossRef]

11. Govaerts, R.; Dransfield, J.; Zona, S.F.; Hodel, D.R.; Henderson, A. World Checklist of Selected Plant Families. Facilitated by the Royal Botanic Gardens, Kew. Published on the Internet. Available online: http:/ /wcsp.science.kew.org/ (accessed on 3 December 2020).

12. Kreutz, C.A.J.; Fateryga, A.V.; Ivanov, S.P. Orchids of the Crimea; Kreutz Publishers: Landgraaf, The Netherlands, 2018 ; p. 576.

13. Nicolè, F.; Brzosko, E.; Till-Botraud, I. Population viability analysis of Cypripedium calceolus in a protected area: Longevity, stability and persistence. J. Ecol. 2005, 93, 716-726. [CrossRef]

14. Kucharczyk, M. Cypripedium calceolus L.; Obuwik pospolity. In Gatunki Roślin. Poradniki Ochrony Siedlisk i Gatunków Natura 2000-podręcznik Metodyczny; Sudnik-Wojciechowska, B., Werblan-Jakubiec, H., Eds.; Tom 9; Ministerstwo Środowiska: Warszawa, Poland, 2004; pp. 107-111.

15. Kolanowska, M.; Jakubska-Busse, A. Is the lady's-slipper orchid (Cypripedium calceolus) likely to shortly become extinct in Europe? -Insights based on ecological niche modelling. PLOS ONE 2020, 15, e228420. [CrossRef]

16. Walther, G.R. Plants in a warmer world. Perspect. Plant Ecol. Evol. Syst. 2004, 6, 169-185. [CrossRef] 
17. Lenoir, J.; Gégout, J.-C.; Marquet, P.A.; de Ruffay, P. A Significant Upward Shift in Plant Species Optimum Elevation During the 20th Century. Science 2008, 320, 1768-1771. [CrossRef]

18. Hoffmann, S.; Irl, S.D.H.; Beierkuhnlein, C. Predicted climate shifts within terrestrial protected areas worldwide. Nat. Commun. 2019, 10, 4787. Available online: https:/ / www.nature.com/articles/s41467-019-12603-w (accessed on 18 January 2021). [CrossRef]

19. Araújo, M.B.; Alagador, D.; Cabeza, M.; Nogués-Bravo, D.; Thuiller, W. Climate change threatens European conservation areas. Ecol. Lett. 2011, 14, 484-492. [CrossRef] [PubMed]

20. Likens, G.E.; Lindenmayer, D.B. Integrating approaches leads to more effective conservation of biodiversity. Biodivers. Conserv. 2012, 21, 3323-3341. [CrossRef]

21. Kull, T. Fruit-set and recruitment in populations of Cypripedium calceolus L. in Estonia. Bot. J. Linn. Soc. 1998, 126, 27-38. [CrossRef]

22. Kull, T. Cypripedium calceolus L. J. Ecol. 1999, 87, 913-924. [CrossRef]

23. Delforge, P. Orchids of Europe, North Africa and the Middle East; Timber Press: Portland, Oregon, $2006 ;$ p. 640.

24. Justić, M.; Bučar, M.; Vizec, P.; Vukres, A.; Šegota, V.; Vuković, N. The rare and endangered orchid Cypripedium calceolus L. in Croatia-refound in Gorski Kotar (West Croatia) after 126 years. Nat. Croat. 2020, 29, 55-62. [CrossRef]

25. Baumann, H.; Künkele, S.; Lorenz, R. Die Orchideen Europas. Mit angrenzenden Gebieten; Eugen Ulmer KG: Stuttgart, Germany, 2006; p. 336.

26. Kaźmierczakowa, R. Polish Red List of Pteridophytes and Flowering Plants; Institute of Nature Conservation Polish Academy of Sciences: Krakow, Poland, 2016; 44p.

27. IUCN Species Survival Commmission (SSC). IUCN Red list Categories and Criteria, Version 3.1 IUCN Species Survival Commission; IUCN: Gland, Switzerland; Cambridge, UK, 2001.

28. Melnyk, V.I.; Shynder, O.I.; Nesyn, J.D. Distribution of Cypripedium calceolus (Orchidaceae) in Ukraine. Ukraiskij Bot. J. 2018, 75, 20-32. [CrossRef]

29. Melnyk, V.I.; Shynder, O.I.; Nesyn, J.D. Habitats and current state of populations of Cypripedium calceolus (Orchidaceae) in Ukraine. IBID 2018, 75, 160-168. [CrossRef]

30. Oksanen, J.; Blanchet, F.G.; Friendly, M.; Kidt, R.; Legendre, P.; McGlinn, D.; Minchin, P.R.; O’Hara, R.B.; Simpson, G.L.; Solymos, P.; et al. Vegan: Community Ecology Package. R Package Version 2.5-6. 2019. Available online: https://cran.r-project. org/web/packages/vegan/index.html (accessed on 18 January 2021).

31. Phillips, S.J.; Dudík, M.; Schapire, R.E. A maximum entropy approach to species distribution modeling. In ICML ‘04. In Proceedings of the Twenty-First International Conference on Machine Learning, New York, NY, USA, 4-8 July 2004 ; pp. 655-662.

32. Phillips, S.J.; Anderson, R.; Schapire, R.E. Maximum entropy modeling of species geographic distributions. Ecol. Modell. 2006, 190, 231-259. [CrossRef]

33. Elith, J.; Phillips, S.J.; Hastie, T.; Dudík, M.; Chee, Y.E.; Yates, C.J. A statistical explanation of MaxEnt for ecologists. Divers. Distrib. 2011, 17, 43-57. [CrossRef]

34. Szczęśniak, E.; Jakubska-Busse, A.; Śliwiński, M. Zróżnicowanie i rozmieszczenie zbiorowisk z udziałem Cypripedium calceolus L. (Orchidaceae) na Dolnym Śląsku. Acta Bot. Sil. 2012, 8, 97-128.

35. Wild, J.; Kaplan, Z.; Danihelka, J.; Petř́́k, P.; Chytrý, M.; Novotný, P.; Rohn, M.; Šulc, V.; Brůna, J.; Chobot, K.; et al. Plant distribution data for the Czech Republic integrated in the Pladias database. Preslia 2019, 91, 1-24. [CrossRef]

36. Heinrich, W.; Lorenz, R. Frauenschuh (Cypripedium calceolus L.)-Die Orchidee des Jahres 1996. Ber. Arbeitskrs. Heim. Orchid. 1996, 13, 61-93.

37. Pop, A. Studiul Populaţiei de Cypripedium calceolus L. din Împrejurimile Oraşului Sovata, Judeţ Mures, Lucrare de Licenţă/Population Study of Cypripedium calceolus L. from the Surroundings of Sovata City; Mures county, license Thesis; Universitatea "Babeş-Bolyai": Cluj-Napoca, Romania, 2006; p. 80.

38. Voronkina, N.V. Cypripedium calceolus L. In Krasnaya Kniga Kaluzhskoy Oblasti; Antokhina, V.A., Ed.; OOO Vash Dom: Kaluga, Russia, 2015; pp. 225-226.

39. Dakskobler, I.; Vreš, B. Ecological characteristics, distribution, and preservation conditions of pteridophytes and spermathophytes of European conservational importance, growing in Slovenian forests. Gozdarski Vestn. 2014, 72, 440-451.

40. Perrino, E.V.; Musarella, C.M.; Magazzini, P. Management of grazing Italian river buffalo to preserve habitats defined by Directive 92/43/EEC in a protected wetland area on the Mediterranean coast: Palude Frattarolo, Apulia, Italy. Euro-Mediterr. J. Environ. Integr. 2020, 13, 1682. [CrossRef]

41. Bilz, M. Cypripedium calceolus, the IUCN Red List of Threatened Species. 2011. Available online: https://www.iucnredlist.org/ species/162021/5532694 (accessed on 18 January 2021).

42. Jackowiak, B.; Celka, Z.; Chmiel, J.; Latowski, K.; Żukowski, W. Red list of vascular flora of Wielkopolska (Poland). Biodiv. Res. Conserv. 2007, 5-8, 95-127.

43. Nowak, A.; Nowak, S.; Spałek, K. Red list of vascular plants of Opole province-2008. Opole Sci. Soc. Nat. J. 2008, 41, 141-158.

44. Jakubska-Busse, A.; Szczęśniak, E.; Śliwiński, M.; Narkiewicz, C. Zanikanie stanowisk obuwika pospolitego Cypripedium calceolus L. 1753 (Orchidaceae) w Sudetach. Przyr. Sudet. 2010, 13, 43-52.

45. Czerepko, J.; Gawryś, R.; Cieśla, A.; Sokołowski, K. Warunki środowiska wpływające na stan zachowania obuwika pospolitego Cypripedium calceolus L. w lasach gospodarczych. Sylwan 2014, 158, 867-874.

46. Blinova, I. Populations of orchids at the northern limit of their distribution (Murmansk Oblast): Effect of climate. Russ. J. Ecol. 2008, 39, 26-33. [CrossRef] 
47. Corkhill, P. Raising Cypripedium calceolus from flask. Orchid. Rev. 1996, 104, 348-352.

48. Shefferson, R.P. Survival cost of adult dormancy and the confounding influence of size in Lady's slipper orchids, genus Cypripedium. Oikos 2006, 115, 253-262. [CrossRef]

49. Eu Commission. Communication from the Commission to the European Parliament, the Council, the European Economic and Social Committee and the Committee of the Regions. A new EU Forest Strategy: For Forests and the Forest-Based Sector. SWD (2013) 342 Final\}, SWD (2013) 343 Final. Available online: https:/ / eur-lex.europa.eu/resource.html?uri=cellar: 21b27c38-21fb-11e3-8d1c-01aa75ed71a1.0022.01/DOC_1\&format=PDF (accessed on 22 January 2021).

50. Druart, P. Etat initial et plan d'action pour Cypripedium calceolus L. Sabot de Vénus (Orchidées) dans le canton de Neuchâtel. Conservatoire Botanique National Alpin, Rapport d'étude. 2007.

51. Pearson, R.G.; Dawson, T.P.; Liu, C. Modelling species distributions in Britain: A hierarchical integration of climate and land-cover data. Ecography 2004, 27, 285-298. [CrossRef]

52. Thuiller, W.; Araújo, M.B.; Lavorel, S. Do we need land-cover data to model species distributions in Europe? J. Biogeogr. 2004, 31, 353-361. [CrossRef]

53. Tsiftsis, S.; Djordjević, V.; Tsiripidis, I. Neottia cordata (Orchidaceae) at its southernmost distribution border in Europe: Threat status and effectiveness of Natura 2000 Network for its conservation. J. Nat. Conserv. 2019, 48, 27-35. [CrossRef]

54. Pearson, R.G. Species' Distribution Modeling for Conservation Educators and Practitioners. Synthesis. Am. Mus. Nat. Hist. Lessons Conserv. 2009, 3, 54-89.

55. Tsiftsis, S.; Djordjević, V. Modelling sexually deceptive orchid species distributions under future climates: The importance of plant-pollinator interactions. Sci. Rep. 2020, 10, 10623. [CrossRef] [PubMed]

56. Liu, H.; Jacquemyn, H.; He, X.; Chen, W.; Huang, Y.; Yu, S.; Lu, Y.; Zhang, Y. The Impact of Human Pressure and Climate Change on the Habitat Availability and Protection of Cypripedium (Orchidaceae) in Northeast China. Plants 2021, 10, 84. [CrossRef]

57. Allan, C.; Stankey, G.H. Adaptive Environmental Management: A Practitioner's Guide; Springer Science \& Business Media: New York, NY, USA, 2011; Volume 351.

58. Wagensommer, R.P.; Medagli, P.; Turco, A.; Perrino, E.V. IUCN Red List evaluation of the Orchidaceae endemic to Apulia (Italy) and considerations on the application of the IUCN protocol to rare species. Nat. Conserv. Res. 2020, 5, 90-101. [CrossRef]

59. Tashev, A.; Kuchtev, D. New floristic records in the Balkans. 40. Phytol. Balc. 2019, 25, 323.

60. Denisova, L.V.; Vakhrameeva, M.G. Rod Bashmachok (venerin bashmachok)-Cypripedium L. In Biological Flora of the Moscow Region; Rabotnov, T.A., Ed.; Part 4; Moscow State University: Moscow, Russia, 1978; pp. 62-70.

61. Kranjčev, R. Hrvatske orhideje. AKD, Zagreb. Bucureşti 2005, 38, 45-56.

62. Randić, M.; Brkljačić, A.; Lukač, G.; Kremer, D. New localities of rare NATURA 2000 species: Pulsatilla grandis Wender, Genista holopetala (Koch) Bald and Cypripedium calceolus L. in the NW Dinarides in Croatia. Nat. Croat. Period. Musei Hist. Nat. Croat. 2013, 22, 95-109.

63. Nikolić, T.; Topić, J. Red Book of Vascular Flora of Croatia. Ministry of Culture; State Institute for Nature Protection: Zagreb, Republic of Croatia, 2005.

64. Procházka, F.; Velísek, V. Orchideje Naší Přírody, 1st ed.; Academia Publishing House of the Czech Academy of Sciences: Prague, Czech Republic, 1983; p. 279.

65. Jersáková, J.; Kindlmann, P. Zásady péče o Orchidejová Stanoviště. 1. Vydání. KOPP nakladatelství: České Budějovice, 2004; p. 151.

66. Zimmermann, F. Die Orchideen Brandenburgs-Verbreitung, Gefährdung, Schutz. Ber. Arbeitskrs. Heim. Orchid. $2019,35,4-147$.

67. Kretzschmar, H. Die statistische Gefährdung des Frauenschuhs im mittleren Deutschland. Ber. Arbeitskrs. Heim. Orchid. 1996, 13, 39-40.

68. Lohr, M.; Beinlich, B.; Grawe, F.; Härtl, K.-H. Förderung von Orchideen im Kreis Höxter durch das Life-Projekt, “Vielfalt auf Kalk“. In Arbeitskreis Heimische Orchideen Nordrhein-Westfalen: Die Orchideen Nordrhein-Westfalens; Kuhn, W., Kupper, D., Lohr, M., Loos, G.-H., Luwe, M., Margenburg, B., Wenker, D., Westphal, G., Wolbeck, D., Eds.; LWL-Museum für Naturkunde: Münster, Germany, 2018; pp. 86-93.

69. Matuszkiewicz, W. The systematic position of thermophilous beechwoods (Cephalanthero-Fagenion) in Poland. Fragm. Flor. Geobot. 2000, 45, 393-412.

70. Matuszkiewicz, J.M.; Kozłowska, A. Orchidaceous" beech forests in the Góry Krowiarki Range (Eastern Sudety Mountains). Fragm. Flor. Geobot. 2000, 45, 373-391.

71. Kucharczyk, M. Obuwik pospolity Cypripedium calceolus. In Monitoring Gatunków Roślin, Przewodnik Metodyczny; Perzanowska, J., Ed.; Część I, GIOŚ: Warszawa, Poland, 2010; pp. 83-98.

72. Szelag, Z. Koeleria pyramidata (Poaceae) kommt in Polen vor. Fragm. Flor. Geobot. 1995, 40, 749-753.

73. Săvulescu, T. Flora Republicii Socialiste Romania, XII; Academia Republicii Socialiste Romania: Bucuresti, Romania, 1972.

74. Balázs, Z.R.; Roman, A.; Balazs, H.E.; Căpraş, D.; Podar, D. Rediscovery of Cypripedium calceolus L. in the Vicinity of Cluj-Napoca (Romania) after 80 Years. Contribuţii Botanice 2016, 51, 43-53.

75. Tomescu, C.V. Cypripedium calceolus L. în Pădurea Dragomirna - judeţul Suceava. Horticultură, Viticultură şi vinificaţie, Silvicultură şi grădini publice, Protecţia plantelor 2018, 47, 421-427.

76. Mihãilescu, S.; Strat, D.; Cristea, I.; Honciuc, V. Raportul sintetic privind starea de conservare a speciilor si habitatelor de interes comunitar din România; S.C. Cuget Liber S.A.: Constanta, Romania, 2015; p. 282. 
77. Marinescu, V.M.; Neblea, M.; Marian, M.; Dinuță, C. Land survey and cadastral measurement in horticulture. Curr. Trends Nat. Sci. 2012, 1, 2.

78. Vakhrameeva, M.G.; Varlygina, T.I.; Tatarenko, I.V. Orchids of Russia (Biology, Ecology and Protection); KMK Scientific Press: Moscow, Russia, 2014.

79. Blinova, I. A Northernmost Population of Cypripedium calceolus L. (Orchidaceae): Demography, Flowering, and Pollination. Selbyana 2002, 23, 111-120.

80. Teteryuk, L.; Kirillova, I. Rare and protected Orchids of the Komi Republic. Ber. Arb. Heim. Orchid. 2011, 28, 133-179.

81. Kravchenko, A.V. Compendium of Karelian flora (vascular plants). Karelian Research Centre of the RAS, Petrosavodsk. 2007. (In Russian)

82. Efimov, P.G. Orchids of North-West European Russia (in the Limits of Leningrad, Pskov and Novgorod Regions), 2nd ed.; KMK Scientific Press: Moscow, Russia, 2012.

83. Seregin, A.P.; Borovichev, E.A.; Glazunova, K.P.; Kokoshnikova, Y.S.; Sennikov, A.N. Flora of Vladimir Oblast, Russia: checklist and Atlas; Grif \& K Publisher: Tula, Russia, 2012; p. 620, (In Russian, with English abstract).

84. Sukhorukov, A.P. A Manual of Vascular Plants of Tambov Region; Grif \& K Publisher: Tula, Russia, 2010.

85. Saksonov, S.V.; Koneva, N.V. The abstract of Orchidaceae family [of] the Samara Area. Vestnik of Udmurt State University. Ser. Biol. 2006, 10, 43-50.

86. Shibanova, N.L. Demographic and ecological characteristics of Orchidaceae in Permskii Krai. Permsk. Agrar. Vestn. 2016, 2, 113-128.

87. Suyundukov, I.V. Cypripedium calceolus L. In Krasnaya Kniga Respubliki Bashkortostan; Mirkin, B.M., Ed.; Media Print: Ufa, Russia, 2011; Volume 1, p. 76.

88. Stevanović, V.; Niketić, M.; Lakušić, D. Chorological additions to the flora of eastern Yugoslavia. Flora Mediterr. 1991, 1, 121-142.

89. Niketić, M.; Stevanović, V. Cypripedium calceolus L. In Crvena knjiga flore Srbije 1: Iščezli i krajnje ugroženi taksoni, Zavod za zaštitu prirode republike Srbije, Beograd; Stevanović, V., Ed.; Ministarstvo za životnu sredinu republike Srbije, Biološki fakultet Univerziteta u Beogradu: Beograd, Belgrade, 1999; pp. 222-225.

90. Dakskobler, I.; Rozman, A.; Franz, W.R. Betula pubescens Ehrh. Subsp. carpatica (Willd.) Ascherson \& Graebner, a new taxon in the flora of the Julian Alps and Slovenia and its new association Rhododendron hirsuti-Betuletum carpaticae ass. nov. Folia Biol. Geol. 2012, 53, 5-23.

91. Dakskobler, I.; Anderle, B.; Zupan, B.; Vreš, B. Novosti v flori Slovenije. Hladnikia 2014, 33, 3-30.

92. Tsiftsis, S.; Tsiripidis, I. Threat categories of the Greek orchids (Orchidaceae). Bot. Chron. 2016, 21, 43-74.

93. Tsiftsis, S.; Antonopoulos, Z. Atlas of the Greek orchids; Mediterraneo Editions: Réthymno, Greece, 2017.

94. Available online: http:/ / e-ecodb.bas.bg/rdb/en/vol1/Cypcalce.html (accessed on 18 January 2021).

95. Šilić, Č. Spisak biljnih vrsta (Pteridophyta i Spermatophyta) za Crvenu knjigu Bosne i Hercegovine (in Bosnian). Glasnik zemaljskog Muzeja Bosne i Hercegovine u Sarajevu. Nova Ser. 1996, 31, 323-367.

96. Petrović, D.; Stešević, D.; Vuksanović, S. Materials for the Red book of Montenegro. Nat. Montenegrina 2008 , 7, 605-631.

97. Boscaiu, N.; Coldea, G.; Roreanu, C. Lista rosie aplantelor vasculare disparute, periclitate, vulnerabile si rare din flora Romaniei. Ocrotirea Nat. Mediu. Inconjurător Bucureşti 1994, 38, 45-56.

98. Oltean, M.; Neagrean, G.; Popescu, A.; Roman, N.; Dihoru, G.; Sanda, V.; Mihailescu, S. Lista Roşie a plantelor superioare din România. Inst. Biol. Stud. Sint. Doc. Ecol. Bucur. 1994, 1, 1-52.

99. Oprea, A. Lista Critică a Plantelor Vasculare din România; Editura Universităţii "Alexandru Ioan Cuza": Iaşi, Romania, $2005 ;$ p. 668.

100. IUCN France, MNHN, FCBN, SFO. La Liste rouge des espèces menacées en France-Chapitre Orchidées de France Métropolitaine; Chapitre Orchidées de France métropolitaine: Paris, France, 2010.

101. Dusak, F.; Prat, D. Atlas des Orchidees de France. Biotope, Meze (Collection Parthenope); Museum National d'Histoire Natural: Paris, France, 2010.

102. Rossi, G.; Montagnani, C.; Gargano, D.; Peruzzi, L.; Abeli, T.; Ravera, S.; Cogoni, A.; Fenu, G.; Magrini, S.; Gennai, M.; et al. Lista Rossa della Flora Italiana. 1. Policy Species e altre specie minacciate; Comitato Italiano IUCN e Ministero dell'Ambiente e della Tutela del Territorio e del Mare; Stampera Romana: Roma, Italy, 2013; p. 54.

103. Brusa, G.; Armiraglio, S.; Ceriani, R.M. Monitoraggio delle specie vegetali della Direttiva 92/43/CEE presenti in Lombardia, a supporto della redazione del IV rapporto ex art. 17. Società Botanica Italaiana onlus - Sez. Lombarda, CFA-Regione Lombardia; Varese-Brescia, 2018.

104. Perazza, G.; Perazza, M.D. Cartografia Orchidee Tridentine (COT): Cypripedium calceolus L. e Liparis loeselii (L.) Rich., specie citate nella Direttiva Habitat della CEE. Atti Acc. Rov. Agiati. Ser. 2002, 8, 129-210.

105. eElurikkus, Eesti Ohustatud Liikide Punane Nimestik. 2008. Available online: http://elurikkus.ut.ee/prmt.php?lang=est (accessed on 29 October 2020).

106. Cheffings, C.M.; Farrell, L.; Dines, T.D.; Jones, R.A.; Leach, S.J.; McKean, D.R.; Pearman, D.A.; Preston, C.D.; Rumsey, F.J.; Taylor, I. The Vascular Plant Red Data List for Great Britain; Joint Nature Conservation Committee, Peterborough. Species Status 2005, 7, 1-116.

107. Foley, M.; Clarke, S. Orchids of the British Isles; Griffin Press Publishing Limited: Maidenhead, UK, 2005. 
108. Bañares, Á.; Blanca, G.; Güemes, J.; Moreno, J.C.; Ortiz, S. Atlas y Libro Rojo de la Flora Vascular Amenazada de España. Adenda 2010; Dirección General de Medio Natural y Política Forestal (Ministerio de Medio Ambiente y Medio Rural y Marino); Sociedad Española de Biología de la Conservatión de Plantas: Madrid, Spain, 2010; p. 170.

109. Adenda, Dirección General de Medio Natural y Política Forestal (Ministerio de Medio Ambiente, y Medio Rural y Marino)Sociedad Española de Biología de la Conservación de Plantas, Madrid. 2010. Available online: https:/ /www.miteco.gob.es/fr/ biodiversidad/temas/inventarios-nacionales/921_tcm36-99367.pdf (accessed on 18 January 2021).

110. Averyanov, L.V. Cypripedium calceolus. In Red Data Book of Russian Federation (Plants and Fungi); Bardunov, L.V., Novikov, V.S., Eds.; KMK Scientific Press: Moscow, Russia, 2008; pp. 363-364.

111. Fateryga, A.V.; Efimov, P.G.; Svirin, S.A. Orchids of the Crimean Peninsula; PP “ARIAL" LLC: Simferopol, Crimea, 2019 ; p. 224.

112. Fateryga, V.V. Modern state of the coenopopulation of Cypripedium calceolus (Orchidaceae) in the Crimea. Ekosistemy 2019, 20, 76-81.

113. Available online: https://www.rote-liste-zentrum.de/de/Detailseite.html?species_id=35993\&q=Frauenschuh (accessed on 18 January 2021).

114. Gola, P. Ekobiologické nároky lesních populací střevíčníku pantoflíčku (Cypripedium calceolus L.); Palacký University Olomouc, Faculty of Science. Available online: https:/ theses.cz/id/ddiu4j/ (accessed on 18 January 2020).

115. Grulich, V. Červený seznam rostlin ČR. In Červený Seznam Ohrožených Druhů České Republiky, Přiroda; Grulich, V., Chobot, K., Eds.; Agentura ochrany přírody a krajiny ČR; Tiskárna Bílý Slon: Plzeň, ČR, 2017; pp. 75-132.

116. Available online: https://www.ochranaprirody.cz/pece-o-prirodu-a-krajinu/programy-eu/life/life-ceske-stredohori/cilovedruhy/strevicnik-pantoflicek/ (accessed on 18 January 2021).

117. Elias, P.; Dítě, D.; Kliment, J.; Hrivnák, R.; Feráková, V. Red list of ferns and flowering plants of Slovakia, 5th edition (October 2014). Biologia 2015, 70, 218-228. [CrossRef]

118. Vlčko, J.; Dítě, D.; Kolník, M. Orchids of Slovakia; ZO SZOPK Orchidea: Zvolen, Slovakia, 2003; p. 120.

119. Bornand, C.; Gygax, A.; Juillerat, P.; Jutzi, M.; Möhl, A.; Rometsch, S.; Sager, L.; Santiago, H.; Eggenberg, S. Rote Liste Gefässpflanzen. Gefährdete Arten der Schweiz. Bundesamt für Umwelt, Bern und Info Flora, Genf. Umwelt-Vollzug 2016, 1621, 178.

120. Niklfeld, H.; Schratt-Ehrendorfer, L. Rote Liste gefährdeter Farn- und Blütenpflanzen (Pteridophyta und Spermatophyta) Österreichs. 2. Fassung. In Rote Listen gefährdeter Pflanzen Österreichs. 2. Auflage. Grüne Reihe des Bundesministeriums für Umwelt; Jugend und Familie, Band 10; Austria Medien Service: Graz, Österreich, 1999; pp. 33-152.

121. Pravilnik o uvrstitvi ogroženih rastlinskih in živalskih vrst v rdeči seznam; Uradni list RS 82/2002. Available online: http: / / www.pisrs.si / Pis.web / pregledPredpisa?id=ODRE1883 (accessed on 18 January 2021).

122. Cǔšin, B. Natura 2000 v Sloveniji: Rastline, ZRC SAZU: Biološki inštitut Jovana Hadžija; Založba ZRC: Ljubljana, Slovenia, 2004.

123. Király, G. Vörös Lista. A Magyarországi Edényes Flóra Veszélyeztetett fajai. Red list of the Vascular Flora of Hungary, Saját kiadás; Lővér Print: Sopron, Hungary, 2007; p. 73.

124. Sulyok, J. Boldogasszony papucsa (Cypripedium calceolus). In Környezetvédelmi és Vizügyi Minisztérium Természetvédelmi Hivatal Fajmegörzési Tervek; Természetvédelem: Budapest, Hungary, 2006; p. 66.

125. Lozan, A.; Tofan-Dorofeev, E.; Cotofana, I.; Threatened plant species included in the Emerald Network in Moldova. In Conversation of Plant Diversity; Alexandru, T, ed.; international scientific symposium, 1-3 June 2017; pp. 41. Available online: https://ibn.idsi.md/sites/default/files/imag_file/Conversation\%20of\%20Plant\%20Diversity_1-3_iunie_2017_0.pdf (accessed on 18 January 2021).

126. Gudžinskas, Z.; Ryla, M. Lietuvos Gegužraibiniai (Orchidaceae), Botanikos Instituto Leidykla; Spausdino UAB, Petro Ofsetas: Žalgirio, 2006; p. 104.

127. Bjørndalen, J.E. Protection of Norwegian orchids-A review of achievements and challenges. Eur. J. Environ. Sci. 2015, 5, 121-133. [CrossRef]

128. Ingelög, T.; Andersson, R.; Tjernberg, M. Red Data Book of the Baltic Region. Part 1: Lists of Threatened Vascular Plants and Vertebrates; Swedish Threatened Species Unit Uppsala: Riga, Latvia, 1993.

129. Klavina, D.; Grauda, D.; Priede, A.; Rashal, I. The habitat diversity and genetic variability of Cypripedium calceolus in Latvia. In Proceedings of the Actions for Wild Plants, Papers of the 6th Planta Europa Conference on the Conservation of Plants, Kraków, Poland, 23-27 May 2011; pp. 91-97.

130. Gärdenfors, U. (Ed.) ; Rödlistade arter i Sverige 2010-The 2010 Red List of Swedish Species. ArtDatabanken, SLU, Uppsala; Elanders Sverige AB: Mölnlycke, Sweden, 2010.

131. Hyvärinen, E.; Juslén, A.; Kemppainen, E.; Uddström, A.; Liukko, U.M. The 2019 Red List of Finnish Species; Ympäristöministeriö \& Suomen ympäristökeskus: Helsinki, Finland, 2019; p. 704.

132. Available online: https://bios.au.dk/forskningraadgivning/temasider/redlistframe/soeg-en-art/\#10414 (accessed on 18 January 2021).

133. Daamgard, C.; Moeslund, J.E.; Wind, P. Changes in the Abundance of Danish Orchids over the Past 30 Years. Diversity 2020, 12, 244. [CrossRef] 